

\title{
WHAT NETWORKS DO TO COMPANIES AND WHAT COMPANIES DO TO NETWORKS: EVOLUTION OF ALLIANCE PORTFOLIOS IN NETWORKED MARKETS
}

\author{
Pinar Ozcan*
}

\begin{abstract}
This study explores the question of how alliance portfolios change over time. In the setting of the U.S. wireless gaming market, I collected real-time and longitudinal data on entrepreneurial game publishers over a period of two-and-a-half years. This process revealed that companies' alliance portfolios can grow or deteriorate rapidly through virtuous or vicious cycles depending on their starting position in a networked market. Those companies in a virtuous cycle have the additional advantage that they can use resource-dependence strategies to fuel the virtuous cycle further. Finally, I found that changes in a company's alliance portfolio occur simultaneously with other company-level changes, such as physical growth, new rounds of financing, public offering and game coverage. The findings have potential contributions to literature at the company, portfolio, and network levels. Overall, the picture provided is one that advocates multi-level and longitudinal analysis for the understanding of company, portfolio, and network-level outcomes deriving from company-level interactions and portfolio strategies.
\end{abstract}

* Professor of General Management, IESE

Keywords: Alliance portfolios, company evolution, strategy, resource dependence. 


\section{WHAT NETWORKS DO TO COMPANIES AND WHAT COMPANIES DO TO NETWORKS: EVOLUTION OF ALLIANCE PORTFOLIOS IN NETWORKED MARKETS}

\section{Introduction}

Alliances between companies can have a major influence on company performance (Dyer and Singh, 1998; Gulati and Higgins, 2003). The benefits of inter-company ties include rapid acquisition of knowledge and other resources (Powell et al., 1996; Gulati and Nohria, 1998), lower transaction costs through asset-pooling, economies of scale and scope (Williamson, 1985; Pisano, 1990), and greater legitimacy (Baum and Oliver, 1991; Stuart, 1998; Baum et al., 2000). These benefits can be particularly critical for businesses with limited resources, such as entrepreneurial companies, and in dynamic environments where diverse and changing resources are needed to prosper (Baum et al., 2000; Eisenhardt and Schoonhoven, 1996).

After a long tradition of examining alliances at the dyadic, or pair level (e.g., Larson, 1992; Gulati, 1995; Doz, 1996; Dussauge et al., 2000), researchers have recently begun to extend their interest to alliance portfolios. Portfolios are central components of networks, and can be beneficial to companies. Research suggests that alliance portfolios are an important tool for companies to deal with environmental uncertainty (Eisenhardt and Schoonhoven, 1996; Ozcan and Eisenhardt, 2007). In knowledge-intensive industries, alliance portfolios are known to be a significant driver of innovation (Powell et al., 1996; Madhavan et al., 1998; Doz et al., 2000; Dyer and Nobeoka, 2000).

While various dimensions of alliance portfolio research are developed (such as the companylevel benefits of having an alliance portfolio and the characteristics of a high-performing portfolio), extant research falls short on providing a longitudinal, dynamic view of portfolios. Specifically, our knowledge of how alliance portfolios evolve once they are formed is very limited. Unveiling the process of portfolio change is critical for understanding how companies change and how company strategy and structure interact at the periphery of organizational boundaries. At the market level, understanding this process is important in identifying the processes whose interaction leads to endogenous changes in the market network.

This study explores the question of how alliance portfolios change over time. Within the setting of the U.S. wireless gaming market, a new and networked market where alliance portfolios are 
likely to significantly affect company performance, I collected real-time and longitudinal data on entrepreneurial game publishers, over a period of two-and-a-half years. Given the lack of prior theory and empirical evidence on the topic, I used a multiple-case inductive approach, conducting periodic semi-structured interviews at six focal companies and their key portfolio partners. I complemented this data with quantitative and qualitative archival sources including the Wireless Gaming Review, which gives a complete account of all the wireless games published in the U.S. for the given time period.

The emerging theoretical framework explains the process through which alliance portfolios change over time. First, it reveals that those companies with strong ties to important and prominent partners experience a virtuous cycle in their portfolio, in that they obtain many new partners and much stronger ties within a short time; by contrast other companies experience a vicious cycle, which strongly deteriorates their portfolio within a short time. In addition to these virtuous and vicious cycles, the findings show that certain resource-dependence strategies pursued by the sample companies can help fuel a virtuous cycle further. Finally, I find that changes in a company's alliance portfolio occur simultaneously with other firm-level changes, such as physical growth, new rounds of financing, public offering and game coverage. This suggests a co-evolutionary growth between companies' alliance portfolio, overall size and resources in interdependent markets.

The findings have potential contributions to literature at the company -portfolio-, and networklevels. At the company-level, I observe that ties co-evolve. In particular, ties of competitors to same or similar partners affect one another as companies compete for the attention and resources of a limited number of partners. This competitive view of tie evolution extends prior literature and motivates future studies to observe dyadic tie development in a wider context that includes the interaction of competing and complementary ties.

At the portfolio level, the findings support prior literature that suggests that partners need both resources and existing ties in order to form and strengthen ties in a network (i.e., The Matthew Effect: "rich get richer, poor get poorer"; Merton, 1968). But in addition, data show that strategy plays a role in the development of an alliance portfolio. Executives can affect the strength of their own portfolio, as well as that of their competitors' portfolios, by attempting to change the network around them through resource-dependence strategies.

Finally, at the network level, the paper lays out the process through which markets change endogenously. First, I find that network structure changes through company -and portfoliolevel developments, such as addition and elimination of ties, changes in tie strength, node size and type. In addition, execution of company-level strategy based on resource dependence reasons also changes the network structure by changing the relative importance of different partner types in the network. At the network-level, the data suggest that clusters may form in networks of high interdependence, as a set of different node types work exclusively with one another due to the increasing trust and synergetic growth at the node-level.

Overall, the picture provided is one that advocates multi-level and longitudinal analysis for the understanding of company -portfolio-, and network-level outcomes deriving from companylevel interactions and portfolio strategies. 


\section{Theoretical Background}

An alliance portfolio can be defined as the collection of direct partnerships around a company (Das and Teng, 2002). Scholarly interest in alliance portfolios has its roots in the finding that companies derive a number of benefits from the network of partners in their surrounding. Studies show that having a portfolio of partners can increase rate of innovation (Dyer and Nobeoka, 2000; Doz et al., 2000) and therefore lead to higher market performance (Powell et al., 1996; Madhavan et al, 1998), particularly for entrepreneurial companies (Baum et al., 2000). Alliance portfolios can also be an important tool for companies dealing with environmental uncertainty (Eisenhardt and Schoonhoven, 1996). Recent studies (Santos and Eisenhardt, 2007; Ozcan and Eisenhardt, 2007) show that, particularly in nascent markets characterized by high ambiguity, executives can form partnerships specifically to hedge their bets.

Another stream of literature examines the characteristics of portfolios that lead to higher performance. This stream indicates that large portfolios with resource-rich, diverse and nonredundant partners increase performance (Uzzi, 1997; Baum et al., 2000; Dyer and Nobeoka, 2000; Stuart, 2000). Furthermore, a combination of strong and weak ties is also beneficial because strong ties enable rich and efficient exchanges, while weak ties offer flexibility and new information (Uzzi, 1997; Rowley et al., 2000). Hansen (1999) finds a related tension between number of ties vs. strength, and so cautions that companies can have too many ties to maintain. As markets become more dynamic, it becomes advantageous to have fewer and weaker ties that favor flexibility and new information over efficiency (Davis et al., 2007). Consistent with this reasoning, Rowley and colleagues (2000) find that companies in the dynamic semiconductor industry have more weak ties than companies in the stable steel industry. Theory indicates that high-performing portfolios combine strong ties that enable rich and efficient exchange, and weak ties that enable greater flexibility and exploration (Uzzi, 1997; Rowley et al., 2000). Moreover, portfolios that are centrally embedded within their broader industry network (Powell et al., 1996) with many, diverse partners (Baum et al., 2000) have information benefits that also make them high-performing.

The dominant view of existing research on alliance portfolios is a deterministic view, treating the portfolio as a resource whose composition is determined entirely by the executives of the focal company. While this view has benefits in terms of prescribing characteristics of a desirable portfolio, it is limited in its handling of the interactions between the portfolio and overall company strategy, as well as changes in the environment over time. In a previous study (Ozcan and Eisenhardt, 2007), we showed that ties of one company are directly affected by the changes in the ties of its partners. As a competitor strengthened the tie with a common partner, the focal company's tie lost some strength, suggesting that alliance portfolios ought not to be considered in isolation from their larger network.

This paper is motivated by the idea that alliance portfolios should be studied in a manner that is longitudinal and inclusive of inter-company interactions, in order to understand the processes and interactions that take place around them. In our earlier paper (Ozcan and Eisenhardt, 2007), we attempted to fill this gap through a longitudinal examination of the portfolio formation process. We observed that in a nascent and interdependent market, executives build a high-performance portfolio by approaching prominent partners early in the market because, over time, these highly desired companies become increasingly busy with their partners. During the process of approaching potential partners, we found that playing the tertius iungens role (joining unconnected potential partners) by pursuing tie formation simultaneously with different types of partners helped focal companies form ties. This approach 
leverages the interdependencies between potential partners and increases the worth of the focal company as a connecting node. We found that, in the early days of the nascent market, maintaining redundant ties within each partner category helps executives to hedge risk and increase market information while they wait for the market to enter growth phase.

While the above-mentioned study is a step towards unraveling the portfolio formation process and its consequences for performance at the company- and portfolio-levels, other portfoliorelated processes are still largely unexplored. Specifically, our knowledge of how alliance portfolios change once they are formed is very limited. How does a portfolio change over time as executives strategize, while at the same time the environment changes due to competitive and regulative factors? Understanding the interaction of different forces around an alliance portfolio is the primary purpose of this study. That is, it aims to explore the question of how alliance portfolios change over time.

\section{Methods}

Given the lack of prior research on how alliance portfolios change over time, I used a grounded-theory building approach (Glaser and Strauss, 1967; Eisenhardt, 1989). I conducted a multiple-case, inductive study involving six entrepreneurial companies. Using multiple cases enables a replication logic in which cases are treated as a series of experiments, each serving to confirm or negate inferences drawn from the others (Yin, 1984). The results are typically better suited to generalization and better grounded than those of single-case studies. The research also uses an embedded design (i.e., with multiple levels of analysis) that includes focal companies, their alliances, and alliance portfolio. This design allows the induction of a richer, more reliable model (Yin, 1984).

The research setting is the U.S. wireless gaming market, in which games for wireless phones are produced and sold. The U.S. wireless gaming market emerged in the U.S. in late 1999, and entered growth stage in 2003 (see Appendix 1 for a detailed description of the market). This market is an ideal research setting for various reasons. First, there is high inter-company dependence among different types of companies involved in the market. Prior research shows that inter-company dependence increases the importance of inter-company relationships for company performance (Pfeffer and Salancik, 1982). Second, wireless gaming is a typical nascent market with frequent and non-linear change (Eisenhardt and Bourgeois, 1988; Aldrich and Fiol, 1994). Studies show that alliances are particularly important for the performance of companies operating in these environments (Eisenhardt and Schoonhoven, 1996). Finally, studying this market at the growth stage has the advantage that there is sufficient volume and activity in the market for companies to receive sufficient financial returns on their activities to create differences in financial performance and company size over time.

Within wireless gaming, I chose six entrepreneurial publishers as focal companies. Focusing this study on entrepreneurial companies is useful because entrepreneurial companies are an important component of economic growth (Schoonhoven and Romanelli, 2001) and alliances are critical for these companies to access the external resources they need to prosper (Baum et al., 2000). In addition, the entrepreneurial setting allows the tracing of alliance activities from the founding days of the companies without the complications of left-censoring. Among the different types of entrepreneurial firms, I chose to study publishers because their role in the market makes them highly dependent on direct ties with a wide variety of partners (such as carriers, brand owners, handset manufacturers, technology providers, developers, etc.). In order 
to observe the similarities and differences in the evolution of the sample companies based on their initial alliance portfolio, I chose six entrepreneurial companies with varying portfolios. Two of the companies started the observation with a significant number of strong ties to prominent partners. One other company had moderately strong ties to several prominent partners, and the rest of the companies had portfolios with weak ties to few partners (Tables 1, $2 \mathrm{a}$ and $2 \mathrm{~b}$ ). To further strengthen the robustness of the results and their suitability for generalizations, the sample is stratified by geography, with companies from three important metropolitan locations for wireless gaming: San Francisco, Los Angeles, and Seattle (Table 1).

\section{Data Collection}

There are several data sources for this study. These include interviews, questionnaires, observations, and secondary sources such as databases. The triangulation of data from different resources strengthens the robustness of the findings (Jick, 1979).

The primary source of data collection is semi-structured interviews. I collected qualitative and quantitative data from semi-structured interviews with executives in the focal and partner companies. To mitigate potential subject biases (Golden, 1992; Miller, Cardinal, and Glick, 1997) and obtain a richer, more elaborated model (Schwenk, 1985), I interviewed three to five executives from each company, each of whom had different responsibilities in the formation and governance of their company's external ties. Appendix 2 explains the different types of informants in the focal companies.

Within each focal firm, I carried out interviews in at least five waves over 30 months between June 2003 and December 2005. The initial interviews ranged from 60 to 150 minutes in length, and covered retrospective information about the company's alliance activities since its founding. To minimize cognitive biases and impression management in retrospective data collection, I asked the informants to place themselves back in time, as opposed to providing their opinion about what happened (Huber and Power, 1985; Miller et al., 1997). I enhanced this framing by centering their attention on facts and events, as opposed to opinions, and reminding informants of facts and dates collected through the archival sources (Eisenhardt, 1989). In addition, I triangulated the data by the information gathered from different informants internal and external to the company. After the initial interviews, I followed-up with the informants in approximately four-month intervals to track the real-time changes in the portfolios. Collecting data in at least five waves allowed the collection of real time and retrospective data, and enabled a stronger longitudinal analysis. In this timeframe, I also conducted 60-90 minute interviews with two to three key informants in major partner companies that were identified by the focal company informants. Within the partner firms, the roles of informants ranged from CEO to VP of Wireless Content depending on the structure of the partner firm. Finally, I also conducted six 60-90 minute interviews with industry experts (such as journalists, investors and professors) to triangulate the data received from the focal and partner company informants.

Given its importance, potential informant bias is addressed in several ways. First, interview data was collected in several waves over 30 months. This enabled both real-time and retrospective longitudinal data. This combination is ideal, with the retrospective data enabling efficient data collection of more observations (thus enabling better grounding) and real-time data mitigating retrospective bias (Leonard-Barton, 1990). Second, certain interview techniques were used (such as "courtroom" questioning, event tracking, non-directive questioning) that prior research has 
shown to yield accurate information from informants (Huber, 1985; Huber and Power, 1985). "Courtroom" questioning puts the informants back in the time frame of the events, and then guides them forward through time to produce a chronology (Eisenhardt, 1989). For example, informants described when and how they approached companies for an alliance, how they decided to approach different partners, and what they negotiated. Questions such as broadbrushed interpretations (e.g., why was your portfolio successful?) typically have poor accuracy and were therefore avoided. "Non-directive questioning" refers to avoiding questions about specific constructs until the end of the interview. Third, informants included executives at both focal and partner companies at multiple levels of hierarchy (e.g., CEO and VP levels), and in different functional areas (such as marketing, business development, engineering). This improves the likelihood of a complete, accurate picture due to diverse and triangulating perspectives. I also relied on informants who were particularly knowledgeable about the ties and for whom they were important and recent. Research shows that such informants are highly accurate (Siedler, 1974; Kumar et al., 1993). In addition, highly knowledgeable industry experts were used as an independent data source. Fourth, anonymity was provided for both companies and informants to encourage candor. Finally, to minimize potential informant bias, interview data was supplemented with wide-ranging archival and observational data. I used publications such as analyst reports, journals (including Wireless Gaming Review), the Internet, and internal sources as well as observational data from three industry-wide conferences. In addition, I relied on an extensive database in order to obtain quantitative measures of performance and tie strength. This dataset was created by the primary journal for this market, Wireless Gaming Review, and gives a complete account of all wireless games published in the U.S. from 2003 onward.

\section{Data Analysis}

Data analysis started with individual case studies (Eisenhardt, 1989). First, all interviews were recorded and transcribed. I incorporated the transcripts into a case write-up of the changes in each company's alliance portfolio, integrating the archival sources with the information from the interviews. During the case write-up and analysis, I used a triangulation logic, giving more validity to themes that were supported by different data collections methods and confirmed by several informants (Jick, 1979). At this stage, I analyzed the Wireless Gaming Review and calculated figures such as number of games, number of hit games, and overall visibility in the market for all focal companies (Appendix 4). These figures were integrated into individual cases, which were between 35 and 60 pages, including informant quotes, tables, timelines, and summaries.

The insights from each case were used for within-case and cross-case analyses. In the withincase analysis, events around the focal company were described, and constructs were developed to describe the changes in the portfolios. An additional researcher reviewed the interviews and cases in order to form an independent view and minimize subjective biases, and their input was incorporated into the cases for a better triangulated analysis. The case analysis was followed by the cross-case analysis where I looked for similar constructs across multiple cases. Using charts and tables, case pairs were compared for similarities and differences, and companies were grouped according to potential variables of interest. I refined the emerging findings by revisiting data and looking for the identified pattern in each individual case (Glaser and Strauss, 1967; Yin, 1984). 


\section{RESULTS}

\section{"The Start": Initial Market Conditions and Companies Positions}

As mentioned earlier, the setting for this study is the U.S. wireless gaming market. The U.S. wireless gaming market began in late 1999 with scattered activity by several companies to create games for mobile phones. Until 2003, the market remained in an emergent phase, where activity had started but production and sales volumes were low (see Appendix 1 for details). A background study shows that between 1999 and 2003, executives at the focal companies increasingly realized that wireless gaming was a networked market (or as they called it, an "ecosystem"). ${ }^{1}$ This meant that having an alliance portfolio with various types of partners was necessary in order to operate in this market (see Appendix 1 and Figure 1 for details). Consequently, I observed that at the time of the first interviews in 2003, all focal publishers had already formed ties with several partners and had an operating alliance portfolio. For various reasons ranging from company age to tie-formation strategies (see Ozcan and Eisenhardt, 2007), the portfolios of the focal companies varied in their overall size, the prominence of the individual partners, and the strength of the ties to these partners. Figure 2a illustrates these differences in sample company portfolios at the beginning of data collection. In this comparison, it is noticeable that companies with similar size and background may show high variance in the key characteristics of their alliance portfolio.

\section{The Clock Starts Ticking: Market Enters Growth Stage, Portfolios Change}

As mentioned earlier, data collection for this study started as the wireless gaming market transitioned from emergence to growth stage. I observed that, as the production and sales volumes increased in the market, those companies that had already formed strong ties to prominent partners (i.e., those that had a high performance portfolio) entered a "virtuous cycle"; that is, they experienced a rapid increase in the number of new prominent partners in their portfolio and in the strength of their ties to existing partners.

Topmobile is a good example. Until 2003, Topmobile executives had built a portfolio with ties to most of the prominent U.S. carriers, handset manufacturers, and to many prominent brands (Table and Figure 2a). In a networked market such as wireless gaming, having such a portfolio meant that Topmobile was able to a) publish highly visible games with well-known brand names (such as "The Mission Impossible Game" based on the Tom Cruise blockbuster); b) make the games compatible with the newest Nokia and Motorola phones, and c) publish them on the networks of the top 5 wireless carriers in the U.S. As the Topmobile CEO described, this was " $a$ killer portfolio" that would make Topmobile games successful in the market: "We have the games, we have the connections. Now it's time to make money...”. As Topmobile executives predicted, their games and connections rapidly led to success. Within few months after wireless game platforms were launched, their games were listed among best sellers and the Topmobile name was mentioned frequently in industry reports as a "successful wireless game pioneer".

\footnotetext{
${ }^{1}$ An ecosystem or networked market can be defined as a group of different types of companies that are needed for the creation of a particular product or service (Adner and Kapoor, 2006).
} 
In early 2004, with game sale revenues rolling in and their name all over the press, Topmobile executives were in a good position to add new partners to their portfolio. First, they formed brand ties for two blockbuster action movies, one well-known cartoon, and two major TV sports channels, paying the brand owners high upfront payments for the brand license.

In addition to getting new partners, Topmobile's revenues, popular name, and new partners also helped strengthen ties with current partners. In mid 2004, for instance, Topmobile executives proposed a joint marketing campaign to the number one carrier, which quickly accepted the proposal. The CEO of Topmobile explained, "In June, there was a marketing campaign with 'carrier' for the basketball game. We set the grand prize of a trip for the winner, and they provided the second, third and fourth prizes. Sometimes the carrier itself will come to us like this and say 'We will showcase this phone on this exposition and would like to have your game on it"'.

The campaign became a success, and resulted in high sales figures. Following this success, Topmobile executives noticed that their ties with carriers became even stronger. A VP explained, "Once people see how successful these joint deals are, they come running to you with similar proposals. So we got many deals like this following the 'carrier' deal."

By mid 2004, a virtuous cycle was already forming around Topmobile as the strong ties were bringing in revenues, enabling the executives to improve the portfolio through new ties and stronger existing ties. Following these improvements, Topmobile executives decided that they were in a good competitive position in the market to fuel this cycle even further by raising more capital from investors. When the CEO started his negotiations with various investors, he realized that the investors often based their decisions to fund Topmobile on phone calls to Topmobile's prominent partners. He recalled: "It was because of our strong connections in the market that I kept getting the money!". In August of 2004, Topmobile raised a record amount of money for the market, which was accompanied by extensive press coverage, further improving Topmobile executives' ability to initiate large projects with current partners and form ties with new prominent partners. In October of 2004, they established ties with one of the leading publishers in the video gaming market and signed a licensing agreement for a series of new games. In the second half of 2004, Topmobile also used the additional financial resources to acquire a publisher in the United Kingdom and one in Korea, and a majority shareholding in a Chinese publisher. At the beginning of 2005, Topmobile had become a successful publisher with global distribution.

Their global presence further helped the company in strengthening the portfolio through new ties. Viewing wireless games as an additional marketing channel, brand partners were interested in those publishers who demonstrated a global portfolio. A brand partner executive explained: "More and more, brands are looking for global presence. They don't want to deal with many publishers to distribute the same game across the world". As a global publisher with abundant resources, Topmobile now found it easier to convince prominent potential brand partners. In March of 2005, the executives announced new licensing agreements with prominent music and sports brands. The VP of Marketing explained: “The better we looked, the better the deals got!".

Topmobile's abundant resources and global presence also strengthened the portfolio through stronger ties with existing carrier partners. For instance, making the same game available on many handsets was important both for carriers and publishers because it increased the revenue base from that game for both partners. However, adapting games to handsets was a timeconsuming and expensive process. Therefore, publishers typically only adapted their games to the best-selling handsets. The CEO of a competitor explained: "You have to pick and choose which phones you will develop for. Only the big guys can do it all". Another competitor executive added: "Without money, it's very difficult to be a good partner". Realizing that 
supporting more of a carrier's handsets was a sign of commitment to the carrier, Topmobile executives invested in the development of their games for a larger pool of handsets. This strategy was well-received by the carriers. In late 2005, a carrier executive explained: "It is a sign of their commitment to us and that they are really listening to our needs".

Overall, Topmobile executives leveraged their central portfolio to expand their resources, and to create new opportunities to strengthen their current ties as well as building new ties.

Another example of a company that greatly benefited from a central portfolio and a consequent virtuous cycle is Starclick. Just like Topmobile, Starclick executives already had a central portfolio in 2003, when the wireless gaming market started growing rapidly in the U.S. They had secured strong ties with all of the top carriers, handset manufacturers, and had licensed several prominent brands (Table and Figure 2a).

In many aspects, Starclick experienced the virtuous cycle similarly to Topmobile. In early 2003, Starclick's strong tie to the number three carrier became important when this carrier prepared to launch a new game platform for its handsets. In order to support the launch of the carrier's platform, Starclick executives assigned additional staff and resources to the project. "We were with them from the beginning. We had people working just on that launch when we had so much other stuff going on. Of course, you do that hoping you will be treated by this carrier in a special way. And we were...”.

At the end of this process, Starclick became the publisher with the highest number of games at the carrier. Their games were promoted by the carrier after the launch, and quickly reached high sales numbers. A VP explained: “Our good relationship with them from early on really paid off!".

Like Topmobile, Starclick executives used additional resources to strengthen ties with prominent partners by supporting more of their handsets. In addition, they assigned "account managers" to each carrier tie to improve communication. The CEO explained, "These guys live and breathe for the carrier that they are assigned to. They spend the whole day wondering about how we can serve them better...It's a luxury to have these guys, but they are really worth it!".

In the summer of 2004, as Starclick was obtaining stronger ties and higher revenues, the executives decided to take the company public. Following a successful IP0 in September 2004, which made Starclick highly publicized in the media, the company's alliance portfolio was further strengthened by many new potential partners approaching them to form a tie. An example of this phenomenon is a brand executive, who admitted in an interview at the beginning of 2005, "When we heard about the possibility to license our brand for a game, we looked at the market and decided that we wouldn't make any deals before we met with Starclick... They were our number one choice, so we approached them first!".

Between the fall of 2004 and the fall of 2005, Starclick executives added various new partners to their portfolio. By the end of 2005, Starclick had established stronger ties with existing partners and, added many new prominent partners to the portfolio, and thus had made itself even more attractive as a partner to new companies (Table and Figure $2 b$ ).

The examples of Topmobile and Starclick illustrate that, in a networked market, companies already possessing strong ties to prominent partners enter a "virtuous cycle"; they experience a rapid increase in the number of new prominent partners in their portfolio and in the strength of their ties to existing partners. In contrast, we observe that companies lacking such a stellar 
portfolio experience a "vicious cycle" which strongly deteriorates their alliance portfolio. The following examples illustrate the phenomenon of a vicious cycle around an alliance portfolio.

Compared to Topmobile and Starclick, Airburst's portfolio looked quite modest. In early 2003, while Starclick and Topmobile already were top publisher partners of most prominent U.S. carriers, Airburst was struggling to put together a couple of decent partners in a portfolio. The executives had thus far managed to form ties to only two prominent carriers. In addition, Airburst's portfolio also suffered from weak ties. In 2003, as Topmobile was publishing many games and receiving marketing opportunities from carriers, Airburst executives felt that they were "forgotten" by their two carrier partners. The CEO explained, "We are not getting the attention we want from our key partners. Carriers only pay attention to the top few publishers. They don't see us".

Simultaneous interviews at carriers revealed that indeed, carriers focused on "favorite publishers"; publishers with whom they already had a strong tie. A carrier executive explained, "If we work well with a few partners, we promote them because it is costly to have many partners".

Having few prominent partners and weak ties made it impossible for Airburst games to reach high sales volumes in the market, which severely affected the executives' ability to add new prominent partners to their portfolio. Having no successful track record to show to potential partners, Airburst was simply not an attractive partner candidate. The executives experienced this problem very noticeably in their negotiations with brand owners. The CEO explained, "Brand owners want to see good partners as proof that you can distribute the game. Otherwise, they ask for a lot of money upfront to license their brand."

In 2003 and 2004, while Starclick and Topmobile signed licensing agreements for various prominent brands, Airburst could only license two brands that were less prominent.

In addition to the difficulty of adding new partners to the portfolio, having low-selling games made Airburst an even lower priority partner for the carriers. This happened for several reasons. First, their weak carrier ties and lack of prominent brands gave the executives no means of catching carriers' attention. One carrier executive explained, "Everybody's out there trying to sell a game. So unless we know the guys personally, we screen based on the brand they put on the table".

Second, low revenues kept the executives from meeting carrier partners' expectations in terms of making their games available for different phone types. Since it was a lengthy and expensive process to adapt games to different types of phones, Airburst executives were forced to adapt their games to the most popular handsets while competitors covered a wide range of phones. The CEO of Airburst complained, "Carriers' expect the same kind of technical support from every 'publisher' out there, but it's impossible for guys like us to do!”.

Finally, Airburst was also unable to participate in large joint-development projects with carriers, brands, and handset manufacturers due to a lack of financial resources. Interviews with carrier executives revealed that as the market grew, larger projects (games plus related products, marketing campaigns, etc.) became less risky and more profitable. For such large projects, resourceful publishers such as Starclick were good partners for carriers because, with a resourceful publisher, the carrier could share the development costs. A carrier executive explained "Why would I take the entire risk if I can share it with 'publisher', you know?".

Along the same lines, an Airburst executive admitted "Carriers don't come to us because they know that we can't do what 'competitor' does". 
In summary, not being able to add new partners or strengthen current ties strongly deteriorated Airburst's alliance portfolio (Table and Figure 2b). In mid 2004, the CEO admitted "It is very difficult to survive in this market without partners that back you up".

Another example of a company trapped in the vicious cycle around its portfolio is Mobilate. Like Airburst, Mobilate's portfolio was not very impressive to start with. They only had one strong tie to a prominent carrier; the other two carrier ties were weak. In addition, the brand and handset ties were mediocre (Table and Figure 2a). In a market where alliances were crucial for success, this portfolio led to financial difficulties, which in turn led to difficulties in forming and strengthening ties with prominent companies. During 2004, for instance, Mobilate executives lost several of the brand bids that they entered because competitors could bid higher and demonstrate a stronger portfolio to promote the brand. The CEO explained: "We lost major brands to competition. They went to guys who didn't even need them". In addition, Mobilate executives noticed that, over time, their ties to prominent partners became weaker as stronger competitors strengthened their ties with the same prominent partners, noting, "As they grow on their radar, we become smaller. Naturally...”.

By mid 2004, Mobilate executives were gaining little revenue from game sales and running out of ideas to improve the alliance portfolio with their current human and financial resources.

The examples of Airburst and Mobilate show that companies that lack strong ties to prominent partners suffer from a vicious cycle that further deteriorates their portfolio, dries up their resources, and damages their reputation in the market network. As explained later, both Airburst and Mobilate's overall performance suffered greatly from the vicious cycle around their alliance portfolio (see Section "Company-level changes contemporary with changes in alliance portfolio").

Overall, the data show that networked markets can give way to cycles through which the company either improves its portfolio substantially if it starts out with strong ties to a number of prominent partners, or deteriorates its portfolio quickly if it is lacking such a portfolio. The underlying mechanism for this phenomenon is the feedback loop that emerges between the financial/network resources that an alliance portfolio can provide in an interdependent market, and the usage of these resources to further invest into the strengthening of ties and formation of new ties. That is, companies that have secured a number of prominent partners enjoy the benefits of these relationships in the form of revenues, as well as introductions to other prominent companies in the market. In an interdependent market, executives often use these financial resources to form new ties, and to strengthen existing ties. In addition, they improve their portfolio by forming new ties through the introduction of current partners.

\section{Industry Forces Versus Company Strategy}

An important observation on the phenomenon of virtuous and vicious cycles is that their initiation does not depend so much on the skill set of the management team or the product itself, but rather on whether or not the company can demonstrate an attractive alliance portfolio to current and potential partners. Many informants confirmed this fact. For instance, a carrier executive pointed out: "We only work with people who can bring in the brands and the technology to the table. We don't have time to talk to everyone knocking on our door". A publisher executive complained: "They won't even see our product if they don't already know our name or the brand we bring in". Another executive added: "The doors just got closed on our 
face so soon! ... We didn't get a chance to show what we were about". As these quotes suggest, the weakness of some companies' portfolios left them out of the network of prominent partners while those who already had formed ties with some prominent partners kept getting new ones and stronger ties with current ones.

This might imply that the virtuous and vicious cycles around an alliance portfolio are exogenous forces. Once a company has a certain alliance portfolio to show, the market (i.e., current and potential partners) decides whether or not it will be given the opportunity to improve the portfolio further. In other words, those who already "look good" will be promoted, and others will be neglected. While a strong external force is undeniable in the emergence of these effects, there is evidence that strategy plays a role in the process. Particularly in the case of the companies with high performance portfolios, the data show that certain strategies employed by executives helped fuel this cycle further, adding an endogenous component to the picture. I summarize these strategies below.

The data show that executives of companies in a virtuous cycle did not just "go with the flow"; they also looked for opportunities to fuel it even more through certain competitive strategies. These strategies can be summarized as breaking competitors' ties, preventing potential competition from other node types, and creating competition for their most powerful partners. These strategies helped the firms, either directly or indirectly, to change their network environment to their favor and to improve their portfolio.

\section{Breaking Competitors' Ties}

The first strategy is breaking competitors' ties. Let us understand this strategy through the example of Starclick. As mentioned before, Starclick is one of the companies that already had strong ties to several prominent partners at the beginning of 2003. However, they were still missing a tie to one of the highly prominent carriers in the market. This carrier had an exclusivity agreement with a competitor of Starclick and therefore was not working with any other publishers.

In the spring of 2003, Starclick executives decided that, with their current portfolio and performance, they might have a chance to break this exclusive tie and add this prominent carrier to their own portfolio. The CEO explained: "We were the poster child of mobile games, so we thought, nobody can resist us, let's go for it!". Historically, the carrier executives had turned down requests from all other publishers but the approach of Starclick, a publisher whose portfolio and visibility in the market was much more attractive than their exclusive partner, made them stop and think. One carrier executive explained:

"We felt that a great company like Starclick might serve us better as the market volume increases and we do bigger projects."

As this quote shows, Starclick was chosen partly because of their portfolio, and partly because of their greater size, which allowed them to work on bigger projects with partners. By June of 2003, the carrier executives began to work with Starclick "informally" while they legally terminated the contract with their former partner.

Starclick benefited from this move in two ways. First, their portfolio became more central through the addition of a prominent and important partner to their portfolio. Second, it helped them indirectly by making their competitor's portfolio less central. A Starclick executive explained: "It was good for us, bad for them, so twice as good for us!". 
Another competitive strategy that the companies in a virtuous cycle used was preventing potential competition from other node types. In early 2004, Topmobile executives decided that they needed to try to reduce the importance of brands for their games. Until then, carriers had been promoting branded games, which forced publishers to spend lots of money on licensing brands and share their game revenue with brand partners. In addition, the executives felt that as long as the brands remained critical for game sales, Topmobile was too vulnerable to the threat of brand owners becoming publishers, eliminating Topmobile, and establishing direct ties with carriers. The VP of Business Development stated: " $<$ Brands $>$ are coming into this business, and we need to figure out a way to survive when they cut our ties."

As a solution to this threat, the executives thought about blocking the brand owners' route to the carriers. They could do this by reducing the importance of the brand for the game, which would happen if they could prove to the carriers that games sold very well without brands. The executives decided to put together a collection of their new games, unbranded, and approach carriers to impress and convince them to take these games. One executive explained: "By now $<2004>$, we've become such an important partner to the carriers. I think that if asked, they might actually consider promoting some of our unbranded games". As the last quote indicates, the executives were counting on their track record at the carriers as well as the strength of their tie to accomplish this goal.

Interviews with carriers revealed that this was a relatively insignificant experiment since they could always pull the unbranded games out if they did not sell. One executive explained, "We just threw some in there to see if those guys were right...". In late 2004, Topmobile executives started delivering unbranded games to several carriers. These games were very similar to some of the brand-based best-sellers in the market, but were improved significantly in terms of technology and gaming experience, justifying their promotion to the users. In January of 2005, Topmobile became the only publisher with unbranded games promoted by carriers. At that time, the CEO of a competitor expert indicated: "Only a few publishers have the connections to pull off an unbranded game at this point!". Topmobile's unbranded games became a great success, which encouraged carriers to promote more unbranded games in their network.

The strategy of pushing unbranded games with carriers was a competitive act to decrease the power of brand owners in the market and prevent them from becoming more central to the network. This strategy helped companies fuel the virtuous spiral by ensuring that they could maintain the strength of their most critical ties over time. It also created the additional benefit of improving their finances and allowing the company to gather more resources to grow and strengthen ties with prominent partners.

\section{Creating Competition for Their Most Powerful Partners}

The final strategy of companies to change the network to their favor is to create competition for the most powerful partners. Cellcruise is a good example of a company pursuing this strategy. In mid 2004, Cellcruise executives had built a reasonably high-performing portfolio and were receiving a reasonable amount of revenues from game sales. In their top management meetings at that time, however, the executives noted a problem in their alliance portfolio. One executive described it: "We're too dependent on the carriers, and they still haven't figured out how to sell this stuff!". This problem was not peculiar to Cellcruise; it was one that all publishers faced. In fact, the data show that many publisher executives complained that carriers were not paying 
enough attention to a market that had great potential. In addition, the carriers were not staffed with the right number and quality of people to market and sell wireless games. Here are quotes from several publisher executives on the topic:

- "They are so concerned with their voice business that they don't realize how huge this thing can be!"

- "They have at most 4-5 people in the entire company for the games business. It is ridiculous!"

- "We have to go tell a bunch of 25 year olds how to run this business."

- "They have no idea what to even look for."

Realizing this problem of depending on a partner type that did not meet their company's needs, Cellcruise executives decided to take action. So far, carriers had been the primary distribution channel for wireless games, selling them over the air to their subscribers. By 2004, many other sales channels were possible, including the Internet and docking stations at phone stores or electronic stores. Publishers had been focused mainly on the carriers to strengthen their ties with this partner type in order to "not be left out of the game", as one publisher executive explained. Seeing this trend, which they had followed themselves, Cellcruise executives decided to start negotiations to activate other sales channels.

Their first stop was large retail stores. These stores were already selling mobile phones and were interested in increasing traffic in their electronics department through new offerings. Interviews with one retail store revealed that in order to offer mobile games, they were looking to partner with a company that already had hit games in the market, which would catch consumers' attention. From this aspect, Cellcruise, with several hit sports games in the market, was a good candidate. Cellcruise executives indicate that together with the retail store executives, they developed two concrete plans for mobile game sales in the stores. The first was a docking station at the electronics department, and the second, a "game gift card" next to the cashier, which upon purchase, would get the game sent to the consumer's mobile over the Internet. By the time I finished interviews, the project with the retail stores were in the implementation process. As the Cellcruise CEO put it, both Cellcruise executives and the retail stores were hopeful that "this new channel would somewhat lessen the monopoly of the carriers" in the market over time.

Data show that other firms, e.g., Starclick, followed the same strategy of bringing retail stores into the wireless gaming market, and announced similar alliance deals in 2005.

Resource dependence arguments suggest that companies will try to manage their external relationships in ways that maximize others' dependence on them, and minimize their dependence on other companies (Pfeffer and Salancik, 1982). The above-described strategies are indeed ways in which publisher executives tried to improve their positioning regarding resource dependence. First, the executives convinced partners to cut ties with competitors and therefore increased the partner's dependence on the focal firm. Then, they targeted other types of nodes (e.g., brands) in the network and tried to decrease their power by making their resource less valuable (by publishing unbranded games). Finally, these companies tried to reduce their own dependence on powerful players (e.g., carriers) by forming alliances to introduce other competitive node types (e.g., retail stores) into the network. Overall, these strategies helped companies fuel the virtuous cycle by using their social capital and financial resources to block competitors and reduce the power of other node types in the network. 
Overall, the data show that networked markets can lead to cycles through which the company either improves its portfolio substantially if it starts out with strong ties to a number of prominent partners, or deteriorates its portfolio quickly if it is lacking such a portfolio. Companies that have secured a number of prominent partners enjoy the benefits of these relationships in the form of revenue, as well as introductions to other prominent companies in the market. Executives often use these financial resources to form new ties, and to strengthen existing ties. In addition, they improve their portfolio by forming new ties through the introduction of current partners. While a strong external force is undeniable in the emergence of virtuous and vicious cycles around alliance portfolios, there is evidence that strategy plays an important role in the process as well. Particularly in the case of the companies with high performance portfolios. I observed that certain strategies used by executives helped to fuel this cycle further. These strategies can be summarized as breaking competitors' ties, preventing potential competition from other node types, and creating competition for the most powerful partners (Table 3).

The story told so far in this paper has been one of exogenous and endogenous portfolio change. Uncovering how companies' alliance portfolios change over time is a key step in our understanding of how organizations change at their periphery (see discussion). However, it should be noted that these changes cannot be imagined in isolation from the other processes occurring at the company. In this light, it is helpful to devote the final section to the other changes observed at the sample companies while tracing their portfolios.

\section{Firm-Level Changes Contemporary with Alliance Portfolio Changes}

As shown in Table 4, the companies that experienced a virtuous cycle around their alliance portfolio also experienced several positive changes in their overall growth and position in the market. Take Starclick, for instance: they became the first wireless game publisher to go public in 2005, with great success; they grew rapidly in employee size and number of offices; and won several awards. Similarly, Topmobile raised a record amount of financing in 2004 and opened several offices in the U.S., Europe and Asia.

Compared to these two companies that experienced the virtuous cycle, the other companies we looked at did not go through such positive changes. In fact, two of them exited their market position in different ways, and the other two struggled to survive. Let us start with the story of Airburst. In the course of events that led to Airburst's struggle to survive, their inability to draw more cash from investors played a big role. In late 2004, after seeing that their game sales were not sufficient to continue operations, Airburst's top executives started visiting venture and corporate investors for a round of financing. After a couple of months of visits, the executives realized that they could not convince anyone to make a significant investment because investors familiar with this networked market did not look at the actual product, but at the existing partner portfolio of Airburst. The CEO stated, "They were impressed with our games, but kept asking why we didn't have partners like the other guys... We were trapped. Carriers wanted to see brand partners, brands wanted to see either carrier partners or money, and the investors wouldn't give us money without seeing that we already had these...VC's want to see a strong portfolio. The irony is that we wouldn't need to go to them if we had that portfolio 'cause we'd have money!". 
These last words summarize the vicious cycle that emerged around Airburst as a result of their suffering portfolio. First, without prominent partners and strong ties, Airburst executives could not earn sufficient revenues. The financial difficulties in turn made it even more difficult for Airburst executives to add new partners or strengthen current ties. In turn, not being able to improve their portfolio prevented them from attracting investors, which would have broken this vicious cycle. Finally, in mid 2004, with only weak ties to a few prominent partners and no financial resources to continue, the executives admitted: "We are considering exit strategies because we can't survive in this market with what we have". As a result of their deliberations, the executives decided that instead of "closing shop", they would to leave their role as publisher and become a developer instead. The CTO explained: "We are all computer programmers. So we are good at developing games. If we can't be a publisher, we can at least be a developer". In late 2004, Airburst executives dropped their publisher ties and announced that they were becoming a developer, a company type that did not need various prominent partner types to survive because it would mainly provide support to publishers.

Another company that suffered from a vicious cycle around its portfolio is Mobilate. With a situation strikingly similar to Airburst's (Table and Figure 2b), Mobilate executives found themselves short on cash and attention from their partners; in other words, they had weak ties. In early 2005, during their considerations of what to do, they realized that they might be a good target for acquisition by a foreign/established company that had the reputation and resources to take over Mobilate's portfolio and improve it with an injection of new resources. The CEO explained, "We have the partners, but we are just not high enough on their radar. We need to show them some great stuff to catch their attention at this point!".

After a few months of searching and negotiating, Mobilate was acquired by a prominent European publisher in mid 2005. The new company immediately changed Mobilate's name and started contacting existing partners with new and attractive offers.

Table 4 lists the firm-level changes observed at the sample companies during the period of our data collection. Particular attention was paid to changes in company size and opening of additional offices as indications of growth. Rounds of financing as well as initial public offerings are also notable for these entrepreneurial companies as they indicate the market's trust in company's future. Finally, I noted any major press coverage on the sample companies as an indication of the market's attention to the firm. Together, these events provide a reliable picture of how the companies have changed over two years. In addition to this qualitative account, I examined sample companies' performance over time based on game publishing data. Table 5 explains how sample companies' game coverage changed over two years. Game coverage is a good indicator of a publisher's performance in this interdependent market for several reasons. First, all of the focal companies are start-ups that only sell wireless games. Therefore, their game sales figures are a reflection of their total revenue. Second, availability of games is a good approximation of game sales in this market because, as informants unanimously agreed, the games that have high visibility in this market are likely to be the highest-selling games, and prices are very similar across games. Overall, by calculating the availability of each publisher's games in the market over time, we are able to get a good approximation of their performance in the market. As shown in Table 5 and Figure 3, and consistent with the qualitative account, sample companies Starclick and Topmobile's game coverage increased exponentially over two years while the others showed no growth over the time period.

In this last section, I provide observations on the simultaneity of changes in a company's alliance portfolio with other company-level changes, such as physical growth, new rounds of 
financing, public offering and game coverage. These observations suggest a co-evolutionary growth between a company's alliance portfolio and its overall size and resources. In particular, they suggest that companies with a high-performance alliance portfolio find better opportunities to grow in an interdependent (networked) market and to further enhance their portfolio, while others struggle to survive as their portfolio deteriorates. The underlying mechanism is that companies with strong ties to prominent partners are more likely to perform well financially because they receive more revenues from current ties, and are supported by investors. In addition, these companies are attractive partners to other companies in the network because of those strong ties to prominent partners. As they gain financial resources, these companies can invest into growth in staff and products as well as expansion into new geographical areas. This growth makes them even more attractive to their current partners as well as new partners because they become capable of handling larger projects. In addition, richer companies have the opportunity to strengthen their current ties further because they can improve communication with partners by assigning more human resources to each account. On the other hand, companies with weak ties and less prominent partners are unable to attract enough revenues to invest in current and new ties, without which they are cursed with small size, limited revenues, and unattractive alliance portfolios in an interdependent market. While companies with high-performance portfolios such as Starclick and Topmobile broke records in financing and became success stories in the market, others exited either their position in the market or the market entirely ${ }^{2,3}$.

In the discussion below, I summarize the findings on the virtuous and vicious cycles that emerge around alliance portfolios in an interdependent market, the role of strategy in the process, as well as the consequences for firm-level performance and growth. Finally, I provide links between the findings and various streams of literature.

${ }^{2}$ As explained in the individual examples, the sample companies that experienced this phenomenon all exited their network position in one way or the other. Airburst exited through a change of node type, becoming a developer and accepting a lower revenue potential compared to a publisher. Mobilate, on the other hand, exited by being acquired. Finally, Phonemix used an external, private pool of resources to enter other segments of the market where competition was less intense and their reputation was not damaged.

${ }^{3}$ As explained in the individual examples, the sample companies that experienced this phenomenon all exited their network position in one way or another. Airburst exited through a change of node type, becoming a developer and accepting a lower revenue potential compared to a publisher. Mobilate, on the other hand, exited by being acquired. Finally, Phonemix used an external, private pool of resources to enter other segments of the market where competition was less intense and their reputation was not damaged.

Phonemix is another example of a company affected by the vicious cycle. Realizing that the vicious cycle was keeping them from being an attractive partner to existing and potential partners, Phonemix executives started looking for a way to stop the cycle. Compared to Airburst and Mobilate, Phonemix was more fortunate because the founder was able to boost the company by putting in his private equity. Using this opportunity, Phonemix executives decided to try getting into other segments of mobile entertainment to differentiate themselves from competitors with central portfolios in gaming. At the end of 2004, Phonemix announced: "We are changing our function from a publisher to a "mobile channel of entertainment", which meant that instead of just games, they would now provide a complete package of mobile entertainment (including games, wallpapers, ring tones, news, etc.) based on brands: "We have already started forming alliances that will enable us to bundle these services for mobile consumers as fast as possible". To make this change, Phonemix executives formed ties to several ring tone providers as well as news channels in early to mid 2005 and started working on turning their misfortune around in other market segments. 


\section{Discussion}

Overall, observations suggest that in an interdependent (networked) market, those who build strong ties to prominent partners early on rapidly move ahead of competitors that have weaker ties and fewer prominent partners. At the beginning of the observation period in 2003, which corresponds to the beginning of the growth stage of the wireless gaming market, all of the sample companies had been operating in the market for at least a year. Their size and level of resources were similar ${ }^{4}$. Each had an alliance portfolio; however the portfolios varied in the number of prominent partners as well as strength of ties. During the growth stage of the market, virtuous and vicious cycles emerged around companies' alliance portfolios, and the differences among portfolios turned into differences in the executives' ability to grow the company and enhance alliance portfolio further.

Why do we observe the phenomenon of virtuous and vicious cycles? The wireless gaming market is a networked market (i.e., it has high interdependence between different types of companies). This has several consequences. First, prominent partners (i.e., partners with high status and a large amount of resources) mean more business for the focal firm. In addition, a portfolio with many prominent partners becomes an attractive resource in itself. For this reason, companies that do get prominent partners and reach a high-performing portfolio early on create a lock-in effect in the network: the existing partners become increasingly beneficial for one another and mutually expand the amount of business they do together. There are lowlevels of partner switching. Consequently, other companies that do not have the right partners and strong ties are left in the peripheries of the market with only low levels of activity. While the "insiders" ride the virtuous cycle, the "outsiders" ride the vicious cycle.

While virtuous and vicious cycles appear to be environmental forces that emerge in networked markets, the data reveal that corporate strategy does make a difference, particularly in the virtuous cycle. As companies become larger and better-connected, they can use competitive strategies such as breaking competitors' ties, preventing potential competition from other node types, and creating competition for their most powerful partners to change the network structure in their favor in order to enhance their portfolio and grow at the company-level.

Finally, the data show that the virtuous and vicious cycles observed in this study are strongly linked with sample companies' performance, indicating a co-evolutionary effect between alliance portfolios and company growth/performance in networked markets. Appendix 4 provides a model which the findings suggest for the interaction of alliance portfolios, company growth, and strategy.

\section{Contributions to Literature}

Several links can be drawn from the findings of this study to streams of literature at the company- and market-levels. At the company-level, most of the prior studies consider ties static, and so fail to appreciate that ties strengthen or weaken over time. Through the inductive case method and longitudinal data collection, this paper makes a contribution to alliance and network literatures by uncovering the evolution of ties.

(Co-)Evolution of Ties. One of the underlying mechanisms for the virtuous and vicious cycles is the co-evolution of ties in a network. In particular, the data show that ties of the same type

\footnotetext{
${ }^{4}$ Explain the similarities between company size and position before the cycles. 
(e.g., publisher to carrier) co-evolve based on competition. As a result of companies competing for the attention and resources of prominent partners, some strengthen their ties with the prominent partner, while others cannot. This means that a tie may quickly weaken based on the improvements of the competitor's tie with the same partner. We saw this in the case of Airburst; as companies such as Starclick and Topmobile started offering more games and doing larger projects with the carriers, Airburst executives noticed that the carriers paid them less attention.

This competitive view of tie evolution extends prior literature on interorganizational ties (e.g., Larson 1992; Doz, 1996), which focuses on how dyadic ties can increase or decrease in strength based on partners' interaction. The view of this paper is that ties don't evolve in isolation; they are influenced by the evolution of other ties in their immediate environment. One of the many ways in which this can occur is that the limited attention span of executives at a partner company forces them to focus on the partners that appear most prominent in their portfolio. Dependence of companies on prominent partners and the partners' preference for prominent counterparts creates a co-evolutionary process in the market network. This observation is another motivation for scholars to move away from a dyadic-level understanding of ties and to consider the events at the larger network in order to understand tie development.

The Matthew Effect in Portfolios. The findings also address portfolio development and support prior literature (e.g., Eisenhardt and Schoonhoven 1996; Powell et al., 1996) that suggests that partners need both resources and existing ties in order to form and strengthen ties in a network (i.e., The Matthew Effect: "the rich get richer, the poor get poorer"; Merton, 1968). ${ }^{5}$ But in addition, I observe that strategy plays a role in the development of an alliance portfolio. Executives can affect the strength of their own portfolio, as well as of their competitors' portfolios by attempting to change the network around them through resource-dependent strategies. Specifically, the strategy component of how portfolios change over time, and what this study adds to our existing knowledge based on the Matthew Effect, is the breaking of competitors' ties and either establishing or preventing ties for resource dependence purposes.

Strategy versus Structure. This study at the company-level also contributes to the debate on strategy versus structure (e.g., Hill and Hoskisson, 1987; Rindova and Kotha, 2001). Existing research on this topic is focused mostly on the co-evolution of the two constructs in the internal environment of the company (e.g., Ciaborra, 1996; Galunic and Eisenhardt, 2000). Only recently have scholars begun to explore the external, boundary-related strategies of companies and their interaction with structure (e.g., Santos and Eisenhardt, 2005; Santos, 2006). This study extends this line of research by showing a co-evolutionary process between strategy and structure in the context of the external structure (boundaries) of the company. The data show that the external structure of the company (e.g., alliances and overall portfolio) is affected by both competitive market dynamics (feedback loops) and company strategy. In turn, changes in the external structure (such as the strengthening, weakening, or loss of ties) lead executives to

${ }^{5}$ The phenomenon of virtuous and vicious cycles that I observed can be interpreted as a 'Matthew Effect': "For unto every one that hath shall be given, and he shall have abundance: but from him that hath not shall be taken away even which he hath" (New Testament, The Gospel according to Matthew, 13:12 and 25:29). In his study of scientists, Merton (1968) observed that the same effect holds for the status of scientists, in that high-status researchers receive more credit for their research contribution than low-status researchers with similar levels of research contribution. In this study of alliance networks in wireless gaming, the underlying mechanism for the Matthew Effect is more than just that status leads to more status; it also has a financial component. Those companies that have a set of prominent and important partners benefit from the financial resources and status of their partners in further strengthening their portfolio and growing the firm. 
develop strategies to manage the observed changes. For instance, if the changes are negative in the case of vicious cycles, the companies need to reconsider the organization's overall function and composition of employees. In the case of a virtuous cycle, the external changes may cause executives to apply strategies to enhance their position in the network.

The existence of co-evolutionary processes at the level of ties, and between strategy and structure, has been suggested before (e.g., McKelvey, 1997). However, very few studies have empirically explored these phenomena (e.g., Huygens et al., 2001). This study aims to contribute to this body of work by identifying and building an empirical account for various coevolutionary processes at company- and network levels.

At the network level, the company-level developments described in this paper provide a picture of the endogenous change that dynamic markets go through. The network is constantly restructured through the natural forces of virtuous and vicious cycles, and the competitive strategies that emerge among members of an interdependent network.

Network-Restructuring as a Result of Portfolio Changes and Company Strategy. The changes noted in the previous sections create network-level effects. As alliance portfolios change, the addition and elimination of ties, changes in tie strength, and changes in node size and type are forces that lead to changes in network structure.

The execution of strategy at the company level also changes network structure in various ways. Prior work on resource dependence (e.g., Pfeffer and Salancik, 1982) suggests that companies will organize their internal and external activities so as to minimize their dependence on other companies. We have seen evidence of that as companies in a virtuous cycle tried to reduce their dependencies on important types of partners, such as brands and carriers, by finding ways to continue their operations without them (through publishing unbranded games, and through selling games at retail stores, respectively). As this resource dependence logic forced companies to find alternatives to their most important partners, the importance of different types of nodes in the network started to change. In this case, carriers started to slightly lose importance as retail stores entered the network, and brand owners started to lose importance as publishers started publishing unbranded games. Clearly, one would need to observe several rounds of company behavior in order to provide an accurate account of the changes in the network structure. Future studies at a larger-scale can provide further steps in examining the emerging system-level order and changes in a networked market as the result of actions at the company (agent) level.

Lock-In and Clustering in Interdependent Markets. Prior studies in network literature have primarily focused on why ties form between two actors, the consequences of particular network positions (Burt, 1992) and the development of specific network types, such as scale-free (Albert and Barabási, 1999; Barabási, 2002) or small-world networks (Watts, 1999), through certain network rules. This literature only partially explains formation of clusters because it does not consider the network-level consequences of tie interdependence at the network level.

This study is a potentially important step in uncovering how clusters form, from a bottom-up perspective. As mentioned earlier, early strong ties between a focal company and prominent partners can cause these prominent partners to shut their doors to the focal company's competitors, simply because partner executives cannot take on an infinite number of partners and therefore have to prioritize their own strong ties. While those with strong ties get enough "face time" with the partners to maintain and grow the partners' interest and attention, others with weak ties get ever weaker ties. As illustrated previously, this is not because the latter 
companies have no valuable resources to offer, but rather because they lose visibility in the network. This preference of prominent companies to work with one another creates a lock-in effect in the network: as existing partners with strong ties benefit from their alliance activity, they invest into further expanding their alliance activity, and making themselves less available to others. As a result, companies that lack these initial strong ties are pushed to the peripheries with only low levels of activity. This finding may also be viewed as one of the ways in which clusters may form in networks with high interdependence: companies with strong ties form a tightly linked cluster in the center of the network. This cluster includes companies of different types that are dependent on one another to survive. Over time, the ties among cluster members become stronger and the gap between the central cluster and the 'outsider group' widens.

To conclude, this study is an account of how alliance portfolios change over time, which identifies co-evolutionary processes such as tie evolution and strategy/structure development. In addition, it contributes to extant research on alliance portfolios by observing a Matthew effect in portfolio development, but also by identifying various resource-dependence strategies that add to this effect. Finally, it provides insights on network dynamics such as centrality and cluster-formation as a result of company-level interactions. Overall, the picture provided is one that advocates multi-level and longitudinal analysis for the understanding of company -portfolio-, and network-level outcomes deriving from firm-level interactions and portfolio strategies. 


\section{References}

Afuah, A. (2001), "Dynamic boundaries of the firm: Are companies better off being vertically integrated in the face of a technological change?," Academy of Management Journal 44 (6), pp. 1211-1228.

Albert, R. and A.-L. Barabási (2002), "Statistical mechanics of complex networks," Review of Modern Physics, 74, page 47.

Aldrich, H. E. and C. M. Fiol (1994), "Fools rush in? The institutional context of industry creation," Academy of Management Review, 19 (4), pp. 645-670.

Amit, R., K. R.; MacCrimmon, and C. Zietsma, (2001), "Does money matter?: Wealth attainment as the motive for initiating growth-orientated technology ventures," Journal of Business Venturing, Vol. 16, Issue 2, pp. 119-143.

Barnett, W. P., H. R. Greve et al. (1994), "An Evolutionary Model of Organizational Performance," Strategic Management Journal, 15, Special Issue: Competitive Organizational Behavior, (Winter, 1994), pp. 11-28.

Baum, J., T. Calabrese et al. (2000), "Don't go it alone: alliance network composition and startups' performance in Canadian biotechnology," Strategic Management Journal, 21, pp. 267-294.

Brush, T. H., P.; Bromiley, and M. Hendrickx, (2000), "The free cash flow hypothesis for sales growth and company performance," Strategic Management Journal, 21, pp. 455-472.

Burt, R.S., (1992), “Structural Holes”, Harvard University Press, Cambridge, MA.

Carpenter, M. (2002), "The Implications of Strategy and Social Context of the Relationship between Top Management Team Heterogeneity and Company Performance," Strategic Management Journal, 23, pp. 275-284.

Coles, J. W. and W. S. Hesterly (1998), "The Impact of Firm-Specific Assets and the Interaction of Uncertainty: An Examination of Make or Buy Decisions in Public and Private Hospitals," Journal of Economic Behavior \& Organization, 36, pp. 383-409.

Das, T.K. and B. Teng (2002), "Alliance Constellations: A Social Exchange Perspective," Academy of Management Review, 27 (3), pp. 445-456.

Doz, Y. L. (1996), "The evolution of cooperation in strategic alliances: Initial conditions or learning processes?," Strategic Management Journal, Vol. 17, pp. 55-83.

Doz, Y.L., P.M. Olk, and P.S. Ring (2000), "Formation Processes of R\&D Consortia: Which path to take? Where does it lead?," Strategic Management Journal, 21, pp. 239-266.

Dyer, J.H. (1996), "Does Governance Matter? Keiretsu Alliances and Asset Specificity as Sources of Japanese Competitive Advantage”, Organization Science, 7 (6), pp. 649-666.

Dyer, J. H. and K. Nobeoka (2000), "Creating and managing a high-performance knowledgesharing network: The Toyota case," Strategic Management Journal, 21 (3), pp. 345-367.

Eisenhardt, K. M. (1989), "Building Theories from Case Study Research," Academy of Management Review, 14, pp. 488-511. 
Eisenhardt, K. M. and C. B. Schoonhoven (1996), "Resource-Based View of Strategic Alliance Formation," Organization Science 7 (2), pp. 136-150.

Eisenhardt, K. M. and L. J. Bourgeois, III (1988), "Politics of Strategic Decision Making in HighVelocity Environments: Toward a Mid-range Theory," Academy of Management Journal, 31 (4), pp. 737-770.

Gimeno, J. (2004), "Competition within and between Networks: The Contingent Effect of Competitive Embeddedness on Alliance Formation," Academy of Management Journal, 47 (6), pp. 820-842.

Glaser, B. and A. L. Strauss (1967), "The Discovery of Grounded Theory: Strategies for Qualitative Research," Wiedenfeld and Nicholson, London.

Goerzen, A. and P.W. Beamish (2005), "The effect of alliance network diversity on multinational enterprise performance,” Strategic Management Journal, 26 (4), pp. 333-354.

Golden, B. R. (1992), "The past is the past-or is it? The use of retrospective accounts as indicators of past strategy," Academy of Management Journal, 35 (4), pp. 848-860.

Gomes-Casseres, B. (2001), "The Logic of Alliance Fads: Why Collective Competition Spreads," in "Strategic Alliances and Company Adaptation: A Coevolution Perspective," M.P. Koza, A.Y. Lewin, and M.E. Sharpe (ed.).

Gulati, R., N. Nohria, and A. Zaheer (2000), "Strategic networks," Strategic Management Journal, 21 (3), pp. 203-215.

Gulati, R. and M.C. Higgins (2003), "Which ties matter when? The Effect of Interorganizational Ties on IPO Success,” Strategic Management Journal, 24 (2) pp. 127-144.

Hargadon, A. and R. I. Sutton (1997), "Technology Brokering and Innovation in a Product Development Firm, “Administrative Science Quarterly, 42, pp. 716-749.

Henderson, R. M. and K. B. Clark (1990), "Architectural Innovation: The Reconfiguration of Existing Product Technologies and the Failure of Established Companies," Administrative Science Quarterly, 35, pp. 9-30.

Hill, C. W. L. and R. E. Hoskisson (1987), "Strategy and Structure in the Multiproduct Firm," Academy of Management Review, 12 (2), pp. 331-341.

Huygens, M., C. Baden-Fuller, C., F.A.J. Van den Bosch, and H.W. Volberda (2001), "Coevolution of Company Capabilities and Industry Competition: Investigating the Music Industry, 1877-1997," Organization Studies, 22 (6), pp. 971-1011.

Jick, T. D. (1979), "Mixing qualitative and quantitative methods: triangulation in action," Administrative Science Quarterly, 24, pp. 602-611.

Kale, P., H. Singh, and H. Perlmutter (2000), "Learning and Protection of Proprietary Assets in Strategic Alliances,” Strategic Management Journal, 21 (3), pp. 217-237.

Larson, A. (1992) "Network Dyads in Entrepreneurial Settings: A Study of the Governance of Exchange Relationships," Administrative Science Quarterly, 37, pp. 76-104.

Madhavan, R., B. R. Koka, et al. (1998), "Networks in transition: how industry events (re)shape intercompany relationships," Strategic Management Journal, 19 (5), pp. 439-459. 
McEvily, B., and A. Zaheer (1999), "Bridging Ties: A Source of Company Heterogeneity in Competitive Capabilities”. Strategic Management Journal, 20 (12), pp. 1133-1156.

McKelvey, B. (1997), "Quasi-natural Organization Science," Organization Science, 8, (4), pp. 352-370.

Merton, R.K. (1968), “The Matthew Effect in science,” Science 159, pp. 56-63.

Ozcan, C.P. and K.M. Eisenhardt (2006), "Start-Ups in Nascent Markets: Building a Strong Alliance Portfolio from a Low-Power Position,” Forthcoming.

Penrose, E. (1959), "The Theory of the Growth of the Firm,” Oxford University Press.

Pfeffer, J. and G.R. Salancik, (1982), “Organizations and organization theory,” Pitman, Boston.

Powell, W. W., K. W. Koput, et al. (1996), "Interorganizational Collaboration and the Locus of Innovation: Networks of Learning in Biotechnology," Administrative Science Quarterly 41, pp. 116-145.

Powell, W.W., D.R. White et al. (2005), "Network Dynamics and Field Evolution: The Growth of Inter-organizational Collaboration in the Life Sciences", American Journal of Sociology, 110 (4), pp. 1132-1205.

Podolny, J.M. (1993), “A Status-based Model of Market Competition," American Journal of Sociology, 98 (4), pp. 829-872.

Rindova, V.P. and S. Kotha (2001), "Continuous Morphing: Competing Through Dynamic Capabilities, Form, and Function,” Academy of Management Journal, 44 (6), pp. 1263-1280.

Schoonhoven, C. B. and E. Romanelli (2001), "The entrepreneurship dynamic: origins of entrepreneurship and the evolution of industries," Stanford University Press, Stanford, CA.

Stuart, T., H. Hoang, et al. (1999), "Interorganizational endorsements and the performance of entrepreneurial ventures," Administrative Science Quarterly 44, (2).

Uzzi, B. (1997), "Social Structure and Competition in Intercompany Networks: The Paradox of Embeddedness," Administrative Science Quarterly, 42, pp. 36-67.

Yin, R. K. (1984), "Case Study Research - Design and Methods," Sage Publications, Thousand Oaks, CA. 


\section{Appendix 1:}

History and Structure of the U.S. Wireless Gaming Market

The U.S. wireless gaming industry is a nascent market that emerged in the convergence of the video game and wireless telephony industries. This market began in late 1999 with scattered activity by several companies to create games for wireless phones. These companies were carriers, handset makers, software platforms, brand owners, developers, and publishers, which all were specialized in one aspect of wireless production. Among these different node types in the network, the carriers (such as Verizon Wireless and Sprint), handset makers (such as Nokia and Motorola), software platform providers (such as Qualcomm and Sun Microsystems), and brand owners (such as Suzuki Motors and Disney) were established firms, while the publishers and developers were small entrepreneurial companies.

\section{Figure 1:}

Value Chain in Wireless Gaming

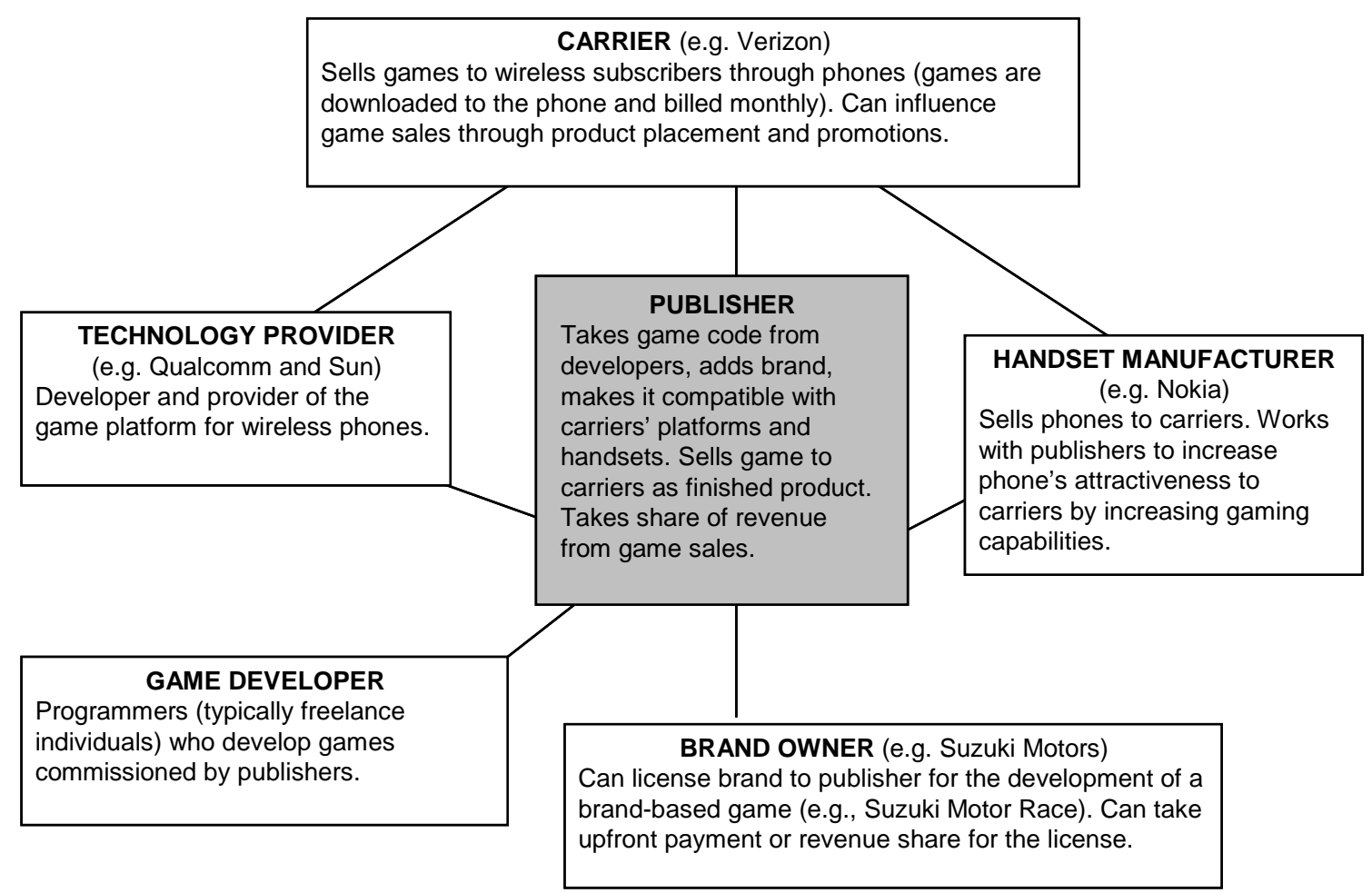

Wireless games have existed in the U.S. since 1999. However, these early games were in WAP format and not user-friendly, so they did not result in wide consumer adoption. It was not until better technology platforms such as Java and BREW were launched that the wireless gaming market entered the growth stage.

The beginning of the growth stage of the market is marked by a visible effort from the carriers to launch the new gaming platforms and promote wireless games. In 2002, there were six national wireless carriers in the US covering more than 200 million subscribers. These carriers each launched a new wireless game platform (Java or BREW) on their network between mid 2002 and mid 2003. 


\section{Wireless Game Platform Launches by Carrier}

- Verizon Wireless: September 2002

- AT\&T Wireless: October 2002, technical problems led to re-launch in November 2003

- Cingular: March 2003

- Sprint: August 2002

- T-Mobile: June 2003

- Nextel: June 2002

After the platforms were launched, the carriers began large advertising campaigns to promote the games on the new platform. Matt Bellows, chief editor of Wireless Gaming Review (the primary online magazine dedicated to wireless games) describes these marketing campaigns: "In Q4 2002, Verizon, Sprint and ATET started advertising. They took out TV ads, print ads, like the first page of USA Today. Verizon had trailers that were running before movies. Even in New York City, they were wrapping little bus kiosks with their stuff".

As part of this campaign, Verizon Wireless, the largest wireless carrier in the U.S. started subsidizing download-capable handsets - consumers could now buy one for \$50 AND get a second one free during the holiday season of 2002. The CEO of Starclick comments, "That move really kick started the install base of the handsets out there so that people could very quickly download, or very quickly get a phone that was capable of downloading these different pieces of entertainment".

Matt Bellows explains, "It was really the 4th quarter of 2002 when all of a sudden consumers could go into a store, buy a phone, download content, and the price of that content would show up on their monthly bill. That was really the crystallizing moment I think".

\section{Market Growth Figures as reported by Carriers}

- Sprint PCS reported that from Q1 to Q3 of 2003, the usage of mobile entertainment services increased from $7 \%$ to $14 \%$. In $2003,40 \%$ of all new subscribers purchased data services. Between August 2002 and May 2003, Sprint sold almost 2 million games, 5 million games in total in 2003, and 3.5 million in the first four months of 2004.

- Verizon Wireless reported that they sold 4 million games in September 2003.

- Cingular Wireless reported that between the platform launch in March 2003 and early 2004, game sales doubled every month.

- In 2003, 30\% of new AT\&T subscribers purchased wireless entertainment services.

Market Growth in Numbers (Overall)

Number of U.S. wireless subscribers who have downloaded games

\begin{tabular}{|c|c|c|c|c|}
\hline Year & 2002 & 2003 & 2004 & 2005 \\
\hline $\begin{array}{c}\text { \# Wireless } \\
\text { Gamers }\end{array}$ & 1260 & 2902 & 5463 & 9424 \\
\hline
\end{tabular}

Source: Gillott Research.

Total Revenue from U.S. Wireless Game Sales

\begin{tabular}{|c|c|c|c|c|}
\hline Year & 2002 & 2003 & 2004 & 2005 \\
\hline $\begin{array}{c}\text { Revenue in } \\
\$\end{array}$ & 21,228 & 56,185 & 127,992 & 250,110 \\
\hline
\end{tabular}

Source: Gillott Research. 


\section{Appendix 2: \\ Data Collection}

The primary source of data collection was semi-structured interviews. I collected qualitative and quantitative data from semi-structured interviews with executives in the focal and partner companies.

Interviews at Focal Firms: Multiple informants were interviewed at two hierarchy levels in each focal firm: CEO and VP levels. Specifically, within the focal firms, I interviewed three to five executives who were responsible for the formation and governance of relationships with the company's partners. Based on pilot interviews, I chose four relevant types of informants within focal companies. The first informant type is an individual with a broad overview of the company's strategy and executions, typically a CEO or a COO. The second type includes individuals who are responsible for making the initial connections, negotiating the deals, and overseeing partner relationships at a broad level. The typical title for of these informants is VP of Business Development or Publishing. The third type of informant, typically VP of Sales and Marketing, works with partners, especially carriers and brands, on a day-to-day basis after the partnership agreement. Finally, the fourth informant type includes individuals overseeing product development, and thus working closely with developers and handset manufacturers. Pilot interviews show that these individuals' titles ranged from VP of Product Development to Chief Creative Officer. 74 interviews were conducted in the focal companies over a span of 30 months.

Interviews outside Focal Firms: In the observation period, I also conducted 60-90 minute interviews with key informants in some of the major partner companies that were identified by focal company informants. Overall, I interviewed informants at the top five U.S. carriers, top two handset manufacturers, technology providers as well as some brand partners. Within the partner firms, the roles of informants ranged from CEO to VP of Wireless Content depending on the function and structure of the partner firm. Finally, I also conducted six 60-90 minute interviews with industry experts (journalists, investors, professors, etc.) to triangulate the data received from the focal and partner company informants. 46 interviews were conducted with partner company informants and industry experts over a span of 30 months.

Interview Guide: I developed three versions of the interview guide. The focal company's interview guide was divided into three sections. In the first section, I asked short-answer questions about the company's background and overall strategy. In the second section, I asked the informant to describe the major events in the formation and evolution of each tie. This section started out by asking the informant to tell the story of each tie, prompting with questions about how the opportunity presented itself, what the underlying logic was, who became involved in the process, what alternatives were considered in the partner selection, and how it was executed. Then, I asked the informant to go through the key developments within the tie, and describe how and by whom these were handled. In addition to these open-ended questions, I asked a set of closed questions including a quantitative evaluation of each tie along several dimensions including goal achievement, communication, trust, conflict, and learning. In the third and final section, I asked the informant questions about the strengths and weaknesses of the current portfolio, and about the company's future strategy for the formation of new ties, and changes in existing ties. In addition to the focal company interview guide, I developed an interview guide for interviews with the partner companies. The partner interview guide had the same overall structure as the focal company interview guide, and focused on publisher ties to triangulate and complement the data obtained from the focal companies. Finally, the interview guide for the industry experts followed a similar structure, but focused on the description of the events and ties that the informant considered key in the overall development of the market. The structure of the interview guides allowed the collection of specific and factual information (such as dates, events, managers involved, issues discussed, key terms, day to day interactions, etc.) as well as more open-ended narrative data.

\section{Table 1:}

Background of Focal Companies (Publishers)

\begin{tabular}{|l|c|c|c|c|c|}
\hline Company & $\begin{array}{c}\text { Founding } \\
\text { Date }\end{array}$ & $\begin{array}{c}\text { Founding } \\
\text { Location }\end{array}$ & $\begin{array}{c}\text { Rounds of Financing } \\
\text { until 2003 }\end{array}$ & $\begin{array}{c}\text { Number of } \\
\text { Employees in 2003 }\end{array}$ & $\begin{array}{c}\text { Number of Offices } \\
\text { Worldwide in 2003 }\end{array}$ \\
\hline Starclick (SC) & 1999 & Los Angeles & 3 & 28 & 1 \\
\hline Topmobile TM & 1999 & Seattle & 3 & 35 & 2 (both U.S.) \\
\hline Cellcruise (CC) & 2000 & San Francisco & 1 & 20 & 1 \\
\hline Mobilate (ML) & 2002 & Los Angeles & 0 & 7 & 1 \\
\hline Phonemix (PM) & 2002 & Seattle & 0 & 25 & 2 (both U.S.) \\
\hline Airburst (AB) & 2002 & San Francisco & 0 & 9 & 1 \\
\hline
\end{tabular}




\section{Appendix 3:}

\section{Characteristics of a High-Performance Alliance Portfolio}

The data show that high-performance portfolios are portfolios with numerous and strong ties to prominent and important partners.

Partner Importance

Focal companies (publishers) typically had four types of partners in the wireless gaming market:

- $\quad$ Carriers, who owned the distribution channel to the wireless subscribers.

- Brand owners whose brand brought additional legitimacy and sometimes content to the game.

- Technology platform providers who owned an industry-standard software platform that publishers used and thus were required for the games.

- Handset manufacturers who provided the handsets to which publishers had to adapt and port their games.

Publishers also collaborated with developers for the writing of game software code. These were mostly free-lance individuals and small companies that worked with publishers on a project basis. Informants did not consider developers as important to their alliance portfolio.

Publishers needed all four of these partner types to operate. However, their dependence on these different partner types varied. In order to measure the level of importance of each partner type, we asked informants to rank partner types in their order of importance for the focal company's success. The data showed that carriers were the most important because they owned distribution and could directly affect game sales (with promotions, deck placement, etc.). Next in importance were brand owners, because a prominent brand was a very influential factor in the consumers' purchasing decision. Informants differed in their ranking of handset manufacturers and technology platform providers. However, all informants agreed that these partners were not nearly as important for the success of the focal company as carriers and brand owners. For technology platform providers, informants explained that it was important to work with the companies at the beginning when the platforms were still being developed. However, once the platforms were launched, the necessity to work with technology platform providers decreased significantly. For handset partners, informants agreed that these ties could be helpful in adapting the games to the latest phones coming to the market. However, informants also stated unanimously that a good carrier tie would provide them with the latest phones coming out and handset ties were not that important to have if the publisher had strong carrier ties.

\section{Partner Prominence}

Once we ranked partner types in their order of importance, we looked at differences among the partners within each type. Different metrics were used to measure the prominence of different types of partners in the portfolio.

- Carriers: Carrier prominence was measured by the U.S. subscriber base of the carrier. The data revealed that there were five prominent carriers in the U.S. at the time of study.

- $\quad$ Brand Owners: Brand prominence was measured through a survey in which 20 students from a major U.S. university (a prototypical target market for wireless gaming) ranked the brands of the focal companies from 1 to 10 where 1 indicated "I don't know this brand at all" and 10 indicated "I know this brand very well". The average of these ratings was then taken for the brands of each focal firm.

- Handset Manufacturers and Technology Platform Providers: As informants stated that these ties did not matter once the market moved out of its emergent stage, the prominence of these partners is irrelevant for the ranking of portfolio centrality at this later stage of the market.

\section{Tie Strength}

Tie strength was assessed using outcome-based measures. Since the nature of the ties to each partner type was different, tie strength was measured differently across partner types.

Tie Strength with Carriers: Tie strength with carriers was measured by the number of games of the publisher on the network of the carrier, as well as the percentage that was promoted by the carrier. These values were taken from the online Wireless Gaming database (www.gamespot.com). These metrics are appropriate for measuring tie strength because the data reveal that the carrier's decision to publish and promote a game was based significantly on the quality of the relationship between the publisher and the carrier. Publishers that did not have a good relationship with the carrier often did not even get a chance to show their games to the carrier. 
In addition, we asked carrier informants to name the top ten publishers in terms of their importance to the carrier. While focal publishers such as Starclick were mentioned in the top ten by all carriers, companies such as Airburst were not named even once as a high priority publisher.

Tie Strength with Brand Owners: Tie strength was not measured for brand partners because publisher informants unanimously stated that once they had the exclusive rights to the brand, the brand partnership required a low level of interaction; therefore tie strength was low. We did, however, note occasions where the same brand owner gave multiple brands to a publisher.

Tie Strength with Platform and Handset Partners: Since handset and technology platform ties did not matter nearly as much to the informants as carrier and brand ties, the strength of these ties are not included in the measurement of portfolio centrality. However, it is worth noting that the strength of these ties varied across publishers. In particular, it is noticeable that those publishers that did not have strong carrier ties and prominent brands approached handset and technology providers for help in making themselves visible in the market. In this, they hoped to gain introductions to other companies (particularly to prominent carrier and brand partners), opportunities to attend exclusive conferences and/or give keynote speeches, and opportunities to co-develop and/or beta test early versions of a phone or platform. Even though some publishers were able to participate in some events through handset and technology ties, these benefits did not affect their performance (in terms of games distribution and sales) in a significant way compared to strong carrier ties and prominent brands.

Overall Portfolio Performance

As explained above, overall portfolio performance is based on the number of strong ties to important and prominent partners. While an absolute ranking of the companies' portfolio centrality is difficult to accomplish, we have calculated portfolio centrality for the focal companies by considering the above mentioned variables in the following order:

- Identifying the number of prominent partners in the most important partner types in descending order (carriers and brand owners).

- Measuring the strength of ties (if applicable) to the prominent partners in these different categories.

- For focal companies that have similar numbers of prominent partners in the most important partner categories (carriers and brand owners), the exact ranking of the overall portfolio centrality is a delicate matter since an extraordinarily strong tie with the most prominent partner may be worth more than strong ties with two slightly less prominent partners in terms of the benefits to the focal company.

- Starclick and Topmobile, for example, are two companies that provide an interesting comparison of portfolio centrality. Starclick has fewer games placed with carriers, but ranks higher in carrier executives' list of most important publishers. Topmobile has more brand partners than Starclick, but their brands are slightly lower rated than Starclick's. While the companies are comparable in terms of the handset relationships, Starclick does better than Topmobile in the technology platform relationships. Overall, while Topmobile seems to have higher volume than Starclick, Starclick has a more central portfolio given the strength of its ties across different partner categories.

- Another interesting comparison is between Cellcruise and Mobilate. While Mobilate has similar numbers to Cellcruise in terms of the number of partners, Cellcruise has a more central alliance portfolio because their ties to important partners (particularly to carriers) are much stronger than those of Mobilate. 


\begin{tabular}{|c|c|c|c|c|c|c|c|c|}
\hline & \multirow[t]{2}{*}{ səłono } & 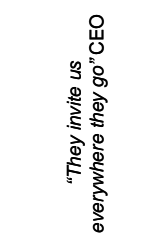 & & \multicolumn{2}{|l|}{ 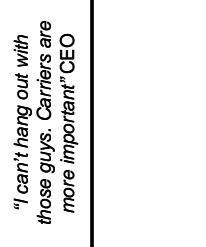 } & 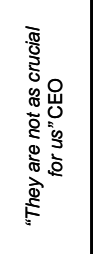 & 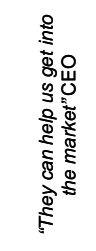 \\
\hline & & & 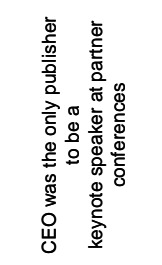 & 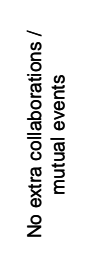 & $\stackrel{s}{z}$ & 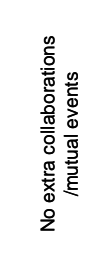 & 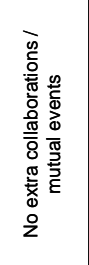 & 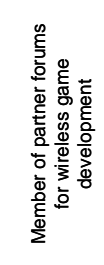 \\
\hline \multirow{13}{*}{ 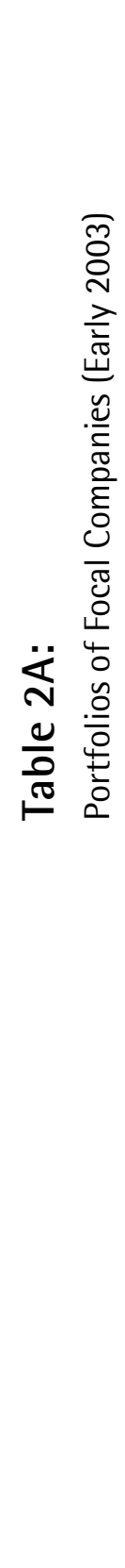 } & \multirow{4}{*}{ 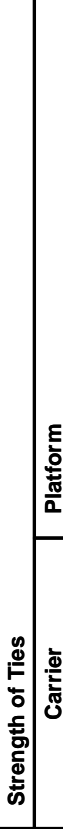 } & salono & 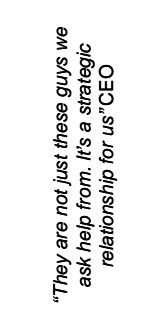 & 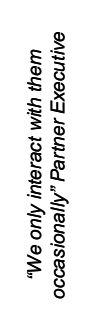 & 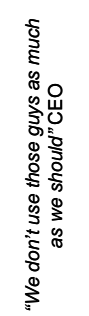 & 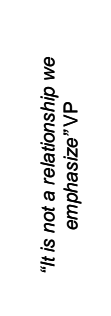 & 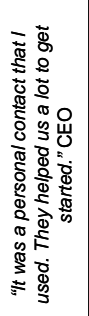 & 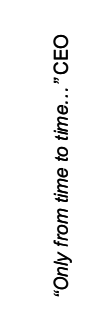 \\
\hline & & słueng & 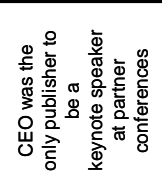 & 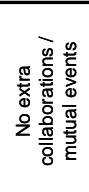 & 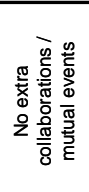 & 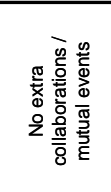 & 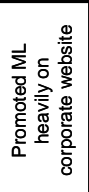 & 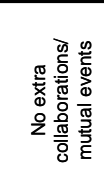 \\
\hline & & 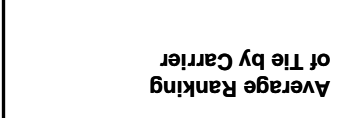 & N & $\stackrel{\circ}{\dot{m}}$ & is & 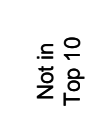 & 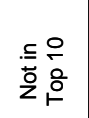 & 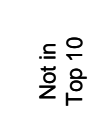 \\
\hline & & $\begin{array}{l}\text { palowodd } \\
\text { saureg \% }\end{array}$ & $\hat{n}$ & $\stackrel{\circ}{\circ}$ & $\infty$ & o & 0 & o \\
\hline & & Iespuen & 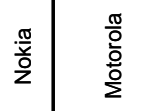 & $\begin{array}{l}\frac{\mathrm{\sigma}}{\mathrm{O}} \\
\frac{\mathrm{O}}{\mathrm{O}} \\
\frac{\mathrm{O}}{2}\end{array}$ & & 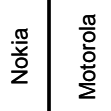 & $\frac{\frac{\pi}{\partial}}{2}$ & 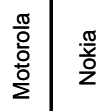 \\
\hline & $\frac{p}{\omega}$ & wopleld & & & 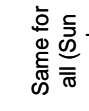 & 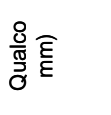 & & \\
\hline & वेّ & $\begin{array}{l}\text { əouวu!wodd } \\
\text { puesg әбеләлt }\end{array}$ & $\underset{\infty}{\infty}$ & 8 & $\hat{\omega}$ & $\frac{\pi}{z}$ & $\stackrel{\circ}{\circ}$ & $\underline{z}$ \\
\hline & | & כגון & 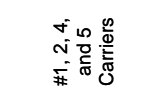 & 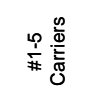 & 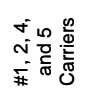 & 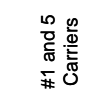 & 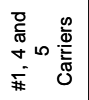 & 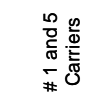 \\
\hline & & słəspueH & $\sim$ & - & $\circ$ & N & - & N \\
\hline & 耪 & swuopleld & n & N & N & n & n & N \\
\hline & 离 & spuesg & $\infty$ & $\sigma$ & $\sigma$ & $\circ$ & $\theta$ & $\circ$ \\
\hline & & 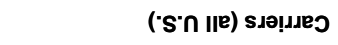 & $\sigma$ & ద & $\sigma$ & N & $m$ & N \\
\hline & & Kuedwoo & O & $\sum$ & O & $\Sigma_{0}$ & $\vec{\Sigma}$ & 电 \\
\hline
\end{tabular}




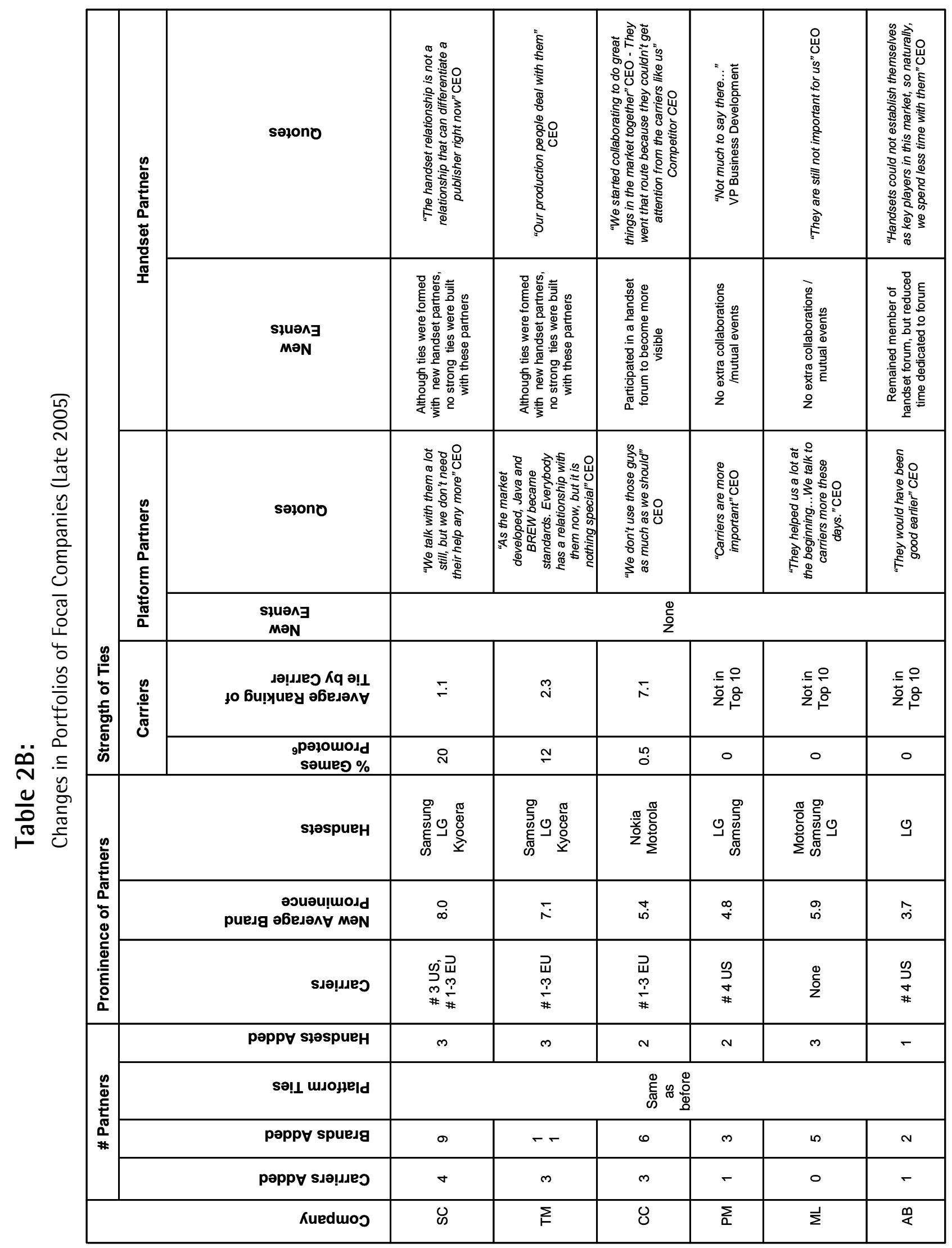
${ }^{6}$ The drop in games promoted by carriers is due to the significant increase in the number of competitors in the
market. 

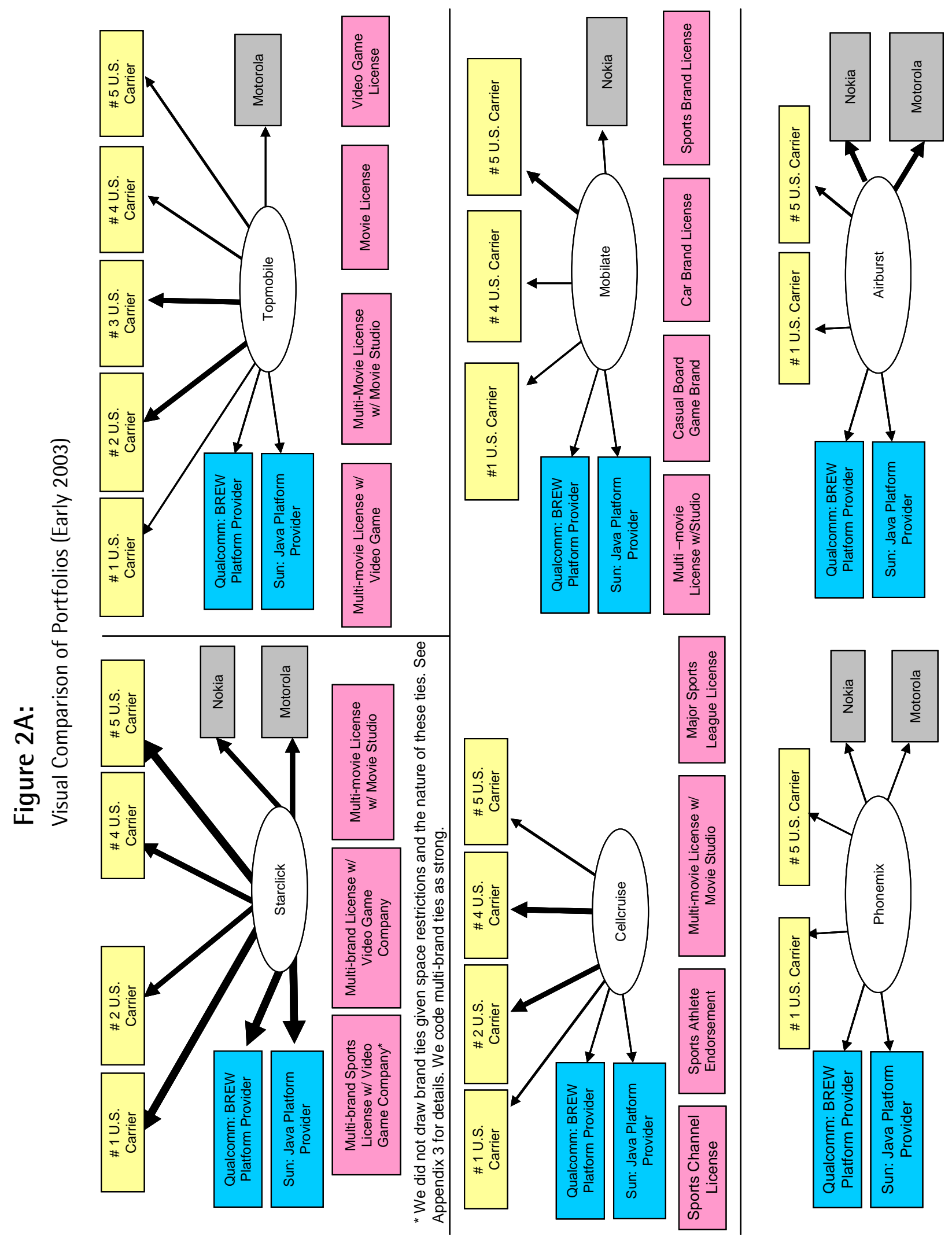


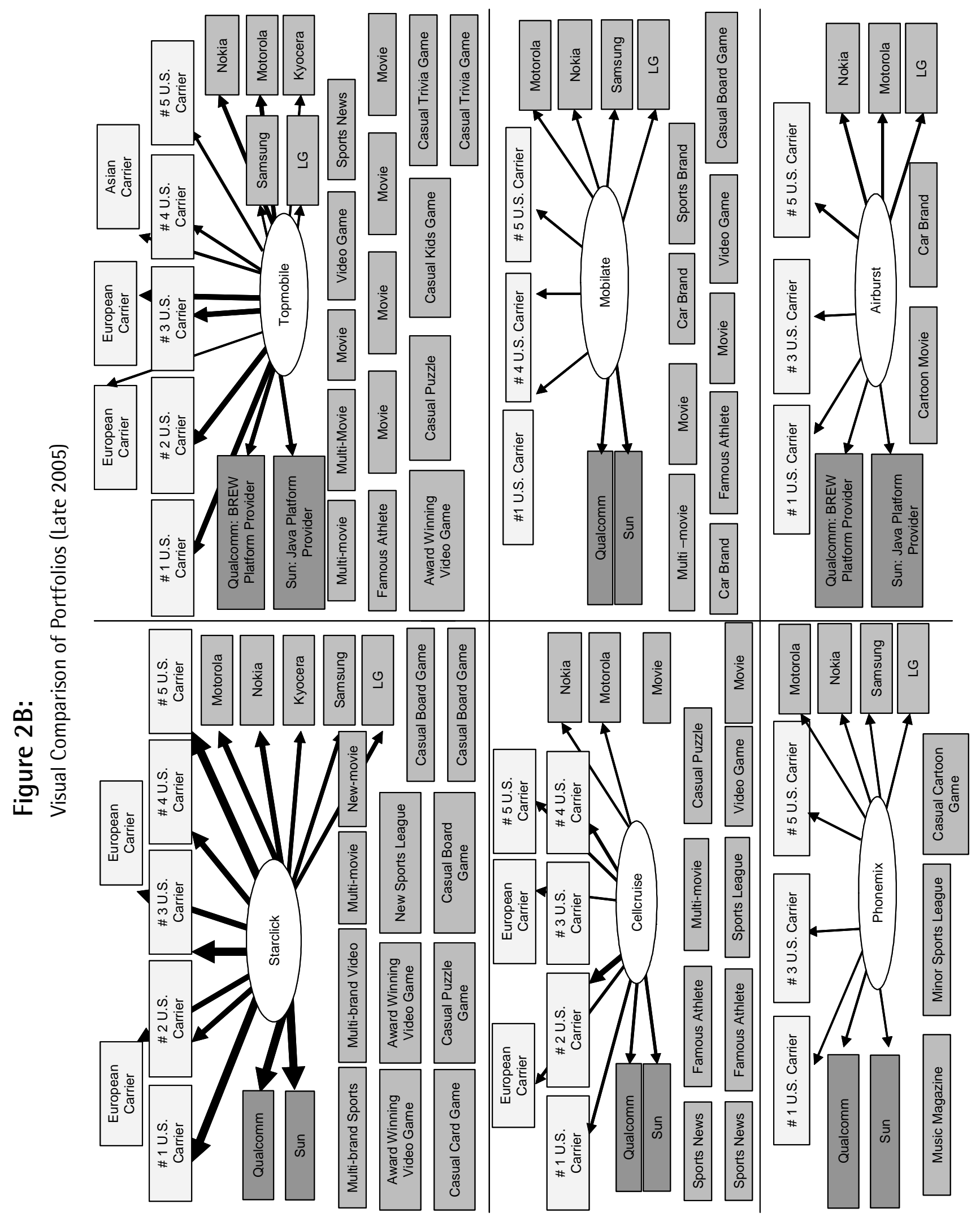




\section{Table 3:}

Overview of Resource Dependence Strategies

\begin{tabular}{|c|c|c|c|}
\hline Firm & $\begin{array}{c}\text { Breaking } \\
\text { Competitors' Ties }\end{array}$ & $\begin{array}{c}\text { Preventing } \\
\text { Competition from } \\
\text { Other Node Types }\end{array}$ & $\begin{array}{l}\text { Creating Competition for } \\
\text { Powerful Partners }\end{array}$ \\
\hline $\begin{array}{l}\text { Starclick } \\
\text { (SC) }\end{array}$ & $\begin{array}{l}\text { Broke competitor's } \\
\text { exclusive tie with } \\
\text { carrier }\end{array}$ & $\begin{array}{l}\text { Tried to de-emphasize } \\
\text { brand owners by } \\
\text { pushing unbranded } \\
\text { games to carriers }\end{array}$ & $\begin{array}{l}\text { Started negotiations with } \\
\text { retailers as an alternative } \\
\text { distribution channel to carriers }\end{array}$ \\
\hline $\begin{array}{l}\text { Topmobile } \\
\text { (TM) }\end{array}$ & $\begin{array}{l}\text { Broke small } \\
\text { competitors' ties } \\
\text { with carrier by } \\
\text { becoming an } \\
\text { intermediary }\end{array}$ & $\begin{array}{l}\text { Tried to de-emphasize } \\
\text { brand owners by } \\
\text { pushing unbranded } \\
\text { games to carriers }\end{array}$ & $\begin{array}{c}\text { Briefly negotiated with online } \\
\text { stores to sell games through } \\
\text { the Internet }\end{array}$ \\
\hline $\begin{array}{l}\text { Cellcruise } \\
\text { (CC) }\end{array}$ & None observed & None observed & $\begin{array}{l}\text { Started negotiations with } \\
\text { retailers as an alternative } \\
\text { distribution channel to carriers }\end{array}$ \\
\hline $\begin{array}{l}\text { Mobilate } \\
\quad(\mathrm{ML})\end{array}$ & None observed & None observed & None observed \\
\hline $\begin{array}{l}\text { Phonemix } \\
\text { (PM) }\end{array}$ & None observed & None observed & None observed \\
\hline $\begin{array}{l}\text { Airburst } \\
\text { (AB) }\end{array}$ & None observed & None observed & None observed \\
\hline
\end{tabular}




\section{Table 4:}

List of Other Events at Focal Companies Between 2003 and 2005

\begin{tabular}{|c|c|c|c|c|c|}
\hline Firm & $\begin{array}{l}\text { New Rounds of } \\
\text { Financing }\end{array}$ & IPO & $\begin{array}{l}\text { Increase in \# } \\
\text { Employees }\end{array}$ & $\begin{array}{l}\text { Opening } \\
\text { of New } \\
\text { Offices }\end{array}$ & Other \\
\hline $\begin{array}{l}\text { Starclick } \\
\text { (SC) }\end{array}$ & $\begin{array}{l}\text { \$11 million in Round } \\
\mathrm{D} \text { (\#1 in industry } \\
\text { worldwide in total } \\
\text { funding received) }\end{array}$ & $\begin{array}{l}\text { Septem } \\
\text { ber } 2004\end{array}$ & $\begin{array}{c}\text { From } 33 \text { to } 120 \text { in } \\
2004 \text { only }\end{array}$ & $\begin{array}{l}\text { Europe } \\
\text { and Asia }\end{array}$ & $\begin{array}{l}\text { Won the "Innovative } \\
\text { Mobile Game" award in } \\
\text { 2004, and "Best Mobile } \\
\text { Games Publisher" } \\
\text { award in } 2005\end{array}$ \\
\hline $\begin{array}{c}\text { Topmobil } \\
\text { e } \\
\text { (TM) }\end{array}$ & $\begin{array}{l}\text { Raised a record of } \\
\$ 44 \text { million in June } \\
2004 \text { (\#2 in industry } \\
\text { worldwide in total } \\
\text { funding received) }\end{array}$ & - & $\begin{array}{c}\text { Hired a 10-person } \\
\text { team at the new US } \\
\text { office }\end{array}$ & $\begin{array}{l}2^{\text {nd }} \text { office } \\
\text { in the } \\
\text { U.S., plus } \\
\text { Europe } \\
\text { and Asia }\end{array}$ & - \\
\hline $\begin{array}{l}\text { Cellcruise } \\
\text { (CC) }\end{array}$ & $\begin{array}{c}\text { Raised } \$ 20 \text { million in } \\
\text { June } 2004 \\
\text { (\#5 in industry } \\
\text { worldwide in total } \\
\text { funding received) }\end{array}$ & - & $\begin{array}{l}\text { Changed CEO in } \\
\text { 2004, no significant } \\
\text { employee increase }\end{array}$ & Europe & $\begin{array}{l}\text { Merged with European } \\
\text { Publisher in early 2005, } \\
\text { received "Best Sports } \\
\text { Game" award for the } \\
\text { year } 2005\end{array}$ \\
\hline $\begin{array}{l}\text { Mobilate } \\
\text { (ML) }\end{array}$ & - & - & - & - & $\begin{array}{l}\text { Acquired by European } \\
\text { publisher in mid } 2005\end{array}$ \\
\hline $\begin{array}{c}\text { Phonemi } \\
\text { X } \\
(\mathrm{PM})\end{array}$ & - & - & $\begin{array}{l}\text { Changed several } \\
\text { executive team } \\
\text { members in } 2004 \\
\text { and } 2005\end{array}$ & - & - \\
\hline $\begin{array}{l}\text { Airburst } \\
\text { (AB) }\end{array}$ & - & - & $\begin{array}{c}\text { Hired } 4 \text { game } \\
\text { developers end of } \\
2004 \text { as they quit } \\
\text { publishing }\end{array}$ & - & $\begin{array}{c}\text { Gave up publishing and } \\
\text { switched to } \\
\text { development in late } \\
2004\end{array}$ \\
\hline
\end{tabular}




\section{Table 5:}

Performance of Sample Companies (in Terms of Overall Visibility of Publishers' Games)

\begin{tabular}{|c|ccrrrr|}
\hline $\begin{array}{c}\text { Time } \\
\text { (quarters) }\end{array}$ & SC & TM & CC & ML & PM & AB \\
\hline $09 / 2003$ & 267 & 500 & 62 & 19 & 3 & 31 \\
$12 / 2003$ & 379 & 595 & 147 & 52 & 10 & 62 \\
$03 / 2004$ & 637 & 905 & 254 & 75 & 16 & 98 \\
$06 / 2004$ & 623 & 851 & 353 & 92 & 22 & 92 \\
$09 / 2004$ & 802 & 889 & 381 & 108 & 28 & 97 \\
$12 / 2004$ & 709 & 711 & 493 & 95 & 26 & 104 \\
$03 / 2005$ & 751 & 884 & 588 & 92 & 55 & 146 \\
$06 / 2005$ & 628 & 957 & 504 & 71 & 29 & 183 \\
\hline
\end{tabular}

I estimated performance for the focal companies based on the availability of the companies' games in the market. Given the emergent stage of the market and the private ownership structure of the majority of publishers, the database does not include sales or revenue information for the games. This is a reliable estimate of companies' revenue base for several reasons. First, all of the focal companies are start-ups that only sell wireless games. Therefore, their game sales figures are an accurate reflection of their total revenue. Second, availability of games is a good approximation of game sales in this market because, as informants unanimously agreed, the games that have high visibility in this market are likely to be the highest-selling games, and prices are very similar across games. Overall, by calculating the availability of each publisher's games in the market over time, we are able to get a good approximation of their performance in the market.

\section{Figure 3:}

Performance Trajectory of Sample Companies (Based on Game Distribution Data)

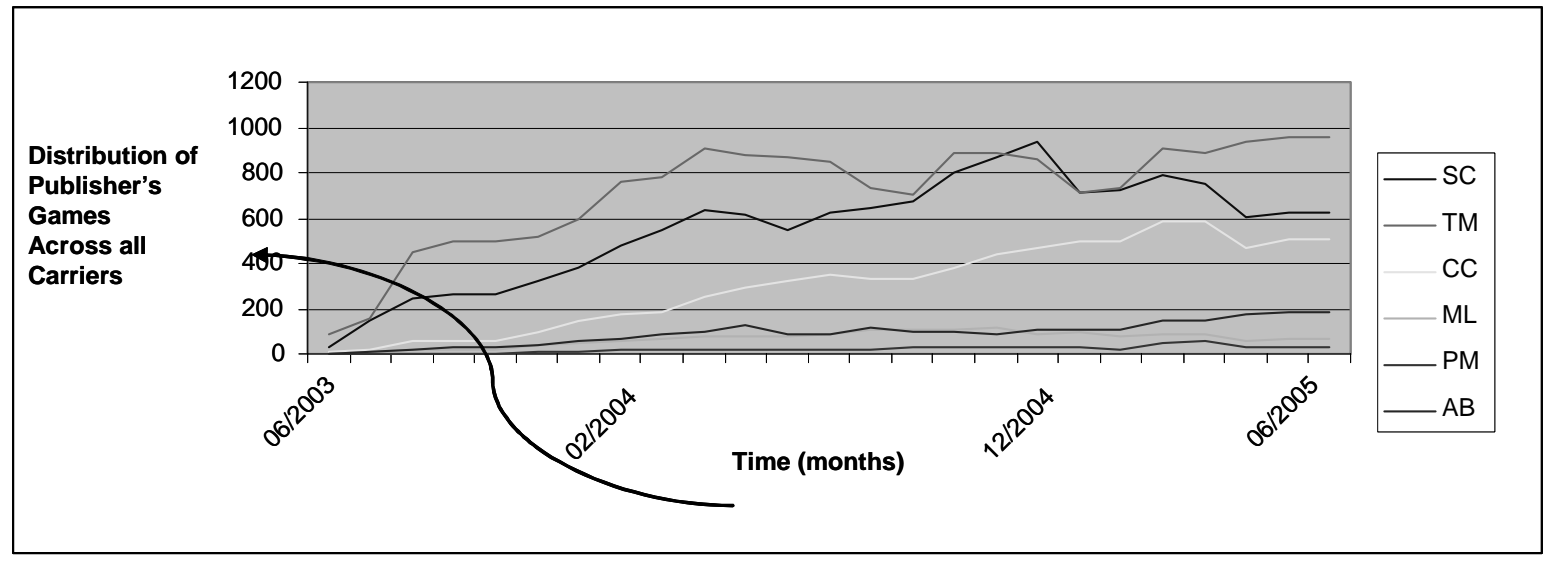




\section{Appendix 4:}

Feedback Loop between Alliance Portfolios and Firm Growth

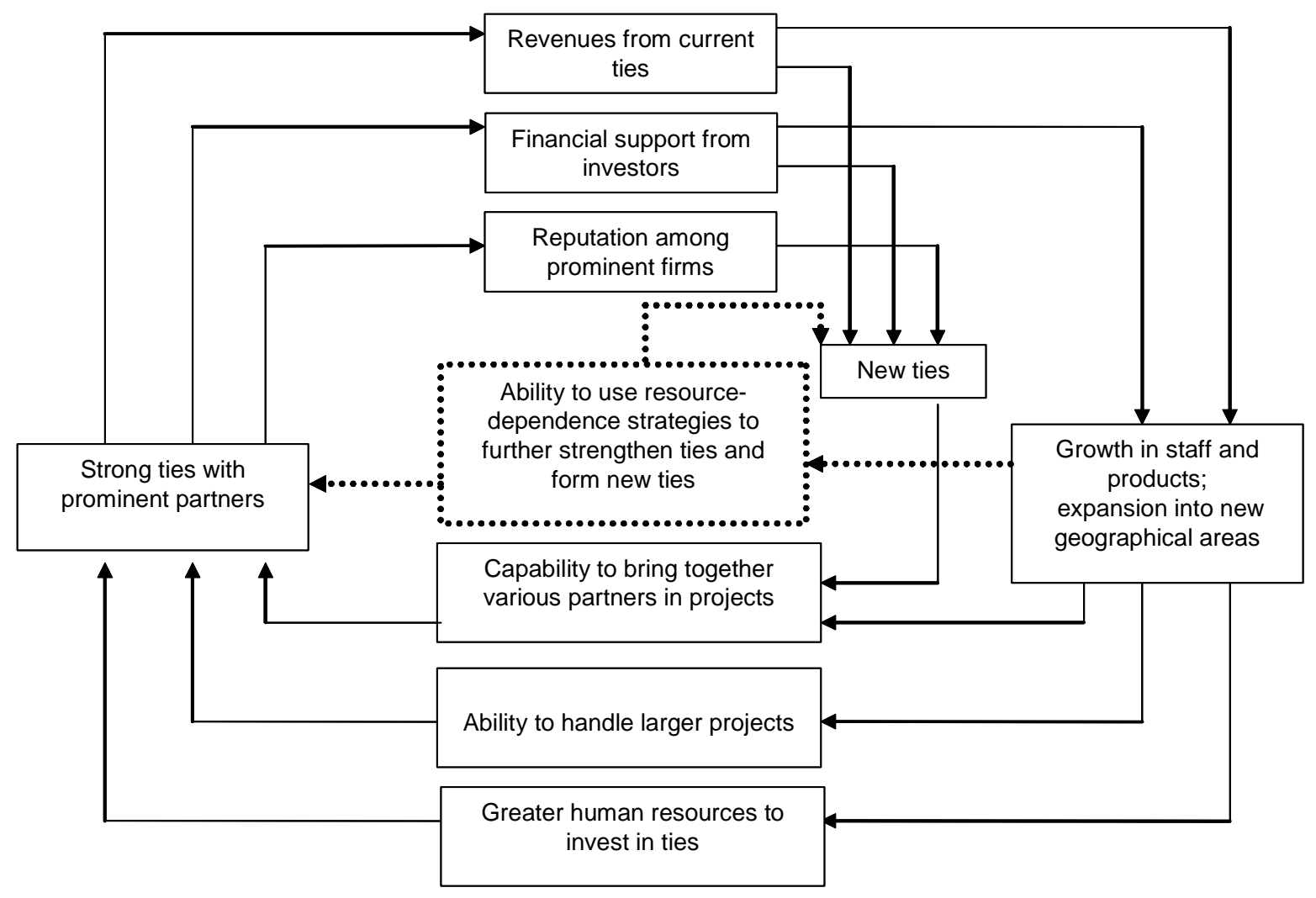

